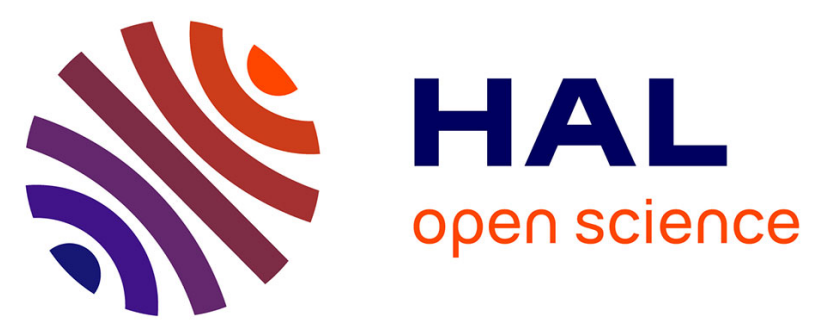

\title{
Pre-Pliocene tectonostratigraphic framework of the Provence continental shelf (eastern Gulf of Lion, SE France)
}

\author{
François Fournier, Aurélie Tassy, Isabelle Thinon, Philippe Münch, \\ Jean-Jacques Cornee, Jean Borgomano, Philippe Leonide, Marie-Odile Beslier, \\ Arnaud Fournillon, Christian Gorini, et al.
}

\section{To cite this version:}

François Fournier, Aurélie Tassy, Isabelle Thinon, Philippe Münch, Jean-Jacques Cornee, et al.. PrePliocene tectonostratigraphic framework of the Provence continental shelf (eastern Gulf of Lion, SE France). Bulletin de la Société Géologique de France, 2016, 187, pp.187-215. 10.2113/gssgfbull.187.45.187. hal-01463727

\section{HAL Id: hal-01463727 https://hal-amu.archives-ouvertes.fr/hal-01463727}

Submitted on 16 Feb 2017

HAL is a multi-disciplinary open access archive for the deposit and dissemination of scientific research documents, whether they are published or not. The documents may come from teaching and research institutions in France or abroad, or from public or private research centers.
L'archive ouverte pluridisciplinaire HAL, est destinée au dépôt et à la diffusion de documents scientifiques de niveau recherche, publiés ou non, émanant des établissements d'enseignement et de recherche français ou étrangers, des laboratoires publics ou privés. 


\title{
Pre-Pliocene tectonostratigraphic framework of the Provence continental shelf (eastern Gulf of Lion, SE France)
}

\author{
FranÇOIS FOURNIER ${ }^{1}$, AURÉlie TASSY ${ }^{1}$, ISABELle THINON ${ }^{2}$, PHILIPPE MÜNCH ${ }^{3}$, JEAN-JACQUes CORNÉE ${ }^{3}$, \\ JEAN BORGOMANO ${ }^{1}$, PHILIPPE LEONIDE ${ }^{1}$, MARIE-ODILE BESLIER ${ }^{4}$, ARNAUD FOURNILLON ${ }^{1,7}$, \\ Christian GORINI ${ }^{5}$, POL GUENNOC ${ }^{2}$, JULIEN OUDET ${ }^{1}$, MARINA RABINEAU ${ }^{6}$, FrançOISE SAGE ${ }^{4}$ \\ and ReNAUd TOULLEC ${ }^{1,8}$
}

\begin{abstract}
Keywords. - Marine geology, Tectonostratigraphy, Seismic stratigraphy, Cretaceous paleogeography, Oligo-Miocene rifting, Post-rift compression.

Abstract. - The seaward extension of onshore formations and structures were previously almost unknown in Provence. The interpretation of 2D high-resolution marine seismic profiles together with the integration of sea-bottom rock samples provides new insights into the stratigraphic, structural and paleogeographic framework of pre-Messinian Salinity Crisis (MSC) deposits of the Provence continental shelf. Seven post-Jurassic seismic units have been identified on seismic profiles, mapped throughout the offshore Provence area and correlated with the onshore series. The studied marine surface and sub-surface database provided new insights into the mid and late Cretaceous paleogeography and structural framework as well as into the syn- and post-rift deformation in Provence. Thick (up to $2000 \mathrm{~m}$ ) Aptian-Albian series whose deposition is controlled by E-W-trending faults are evidenced offshore. The occurrence and location of the Upper Cretaceous South-Provence basin is confirmed by the thick (up to $1500 \mathrm{~m}$ ) basinal series downlaping the Aptian-Albian unit. This basin was fed in terrigenous sediments by a southern massif ("Massif Méridional") whose present-day relict is the Paleozoic basement and its sedimentary cover from the Sicié imbricate. In the bay of Marseille, thick syn-rift (Rupelian to Aquitanian) deposition occurred (>1000 m). During the rifting phase, syn-sedimentary deformations consist of dominant N040 to N060 sub-vertical faults with a normal component and N050 drag-synclines and anticlines. The syn-rift and early post-rift units (Rupelian to early Burdigalian) are deformed and form a set of E-W-trending en echelon folds that may result from sinistral strike-slip reactivation of N040 to N060 normal faults during a N-S compressive phase of early-to-mid Burdigalian age (18-20 Ma). Finally, minor fault reactivation and local folding affect post-rift deposits within a N160-trending corridor localized south of La Couronne, and could result from a later, post-Burdigalian and pre-Pliocene compressive phase.
\end{abstract}

\section{Cadre tectonostratigraphique des formations anté-pliocènes du plateau continental de Provence} (golfe du Lion oriental, SE France)

\begin{abstract}
Mots-clés. - Géologie marine, Tectonostratigraphie, Stratigraphie sismique, Paléogéographie crétacée, Rifting oligo-miocène, Compression post-rift

Résumé. - Le prolongement en mer des formations et des structures provençales était jusqu'alors largement inconnu. L'interprétation de profils de sismique-réflexion marine 2D et l'intégration de dragages et carottages du fond-marin ont permis d'apporter des éléments nouveaux concernant le cadre stratigraphique, structural et paléogéographique des dépôts anté-Messiniens du plateau continental de Provence. Sept unités sismiques post-jurassiques ont été identifiées sur les profils sismiques, cartographiées à travers le plateau continental et corrélées avec les séries affleurant à terre. Une épaisse unité apto-albienne (jusqu'à $2000 \mathrm{~m}$ ) dont le dépôt est contrôlé par des failles E-W a été mise en évidence en mer. L'existence d'un bassin subsident au Crétacé supérieur sur le plateau continental de Provence a été confirmée par le développement d'une épaisse série de bassin (jusqu'à $1500 \mathrm{~m}$ ) reposant en downlap sur l'Apto-Albien. Le socle métamorphique de l'écaille de Sicié et sa couverture sédimentaire peut être considéré comme une relique allochtone du « Massif Méridional » ayant alimenté le Bassin sud-provençal en éléments terrigènes au Crétacé supérieur. Dans la rade de Marseille, une épaisse unité syn-rift (Rupélien à Aquitanien) a été mise en évidence ( $>1000 \mathrm{~m})$, structurée en une série de synformes en échelon d'axe E-W et affectée par des failles d'orientation dominante N040 à N060. Sur le flanc sud des synformes, la formation de plis d'axe N050 est associée à une déformation syn-sédimentaire. La formation des synformes en échelon d'axe E-W résulterait d'une réactivation en décrochement des failles N040 à N060 pendant une phase de compression N-S dont l'âge est compris entre le Burdigalien inférieur et moyen (18-20 Ma). Enfin, les dépôts post-rift sont affectés par des déformations mineures (réactivation de failles et plis associés), le long d'un couloir d'orientation N160 à l'ouest de la baie de Marseille, attribuables à une phase de compression post-burdigalienne et anté-pliocène.
\end{abstract}

1. Aix-Marseille Université, CNRS, IRD, CEREGE UM34, 3 place V. Hugo, 13331 Marseille, France

2. DGR/GBS BRGM, 3 avenue Claude Guillemin, BP 36009, 45100 Orléans, France

3. UMR5243-Géosciences Montpellier, Université Montpellier 2, Place Eugène Bataillon, 34090 Montpellier, France

4. UMR 7329-GéoAzur, 250 rue Albert Einstein, 06560 Valbonne, France

5. Institut des Sciences de la Terre de Paris (iSTeP) CNRS: UMR7193-Université Pierre et Marie Curie (UPMC), 4 place Jussieu, 75005 Paris, France

6. CNRS, UMR6538, Domaines Océaniques, IUEM, 29280 Plouzané, France

7. BEICIP-FRANLAB, 232 Avenue Napoléon Bonaparte, 92500 Rueil-Malmaison, France

8 Institut Polytechnique LaSalle Beauvais, Département Géosciences (GEOS), 19 rue Pierre Waguet, BP 30313 , 60026 Beauvais cedex, France

Manuscript received on February 2, 2016; accepted May 30, 2016 


\section{INTRODUCTION}

The Provence continental shelf is located at the transition between the Gulf of Lion margin and the Ligurian margin. The Gulf of Lion and Ligurian margins are two segments of the northern margin of the Liguro-Provencal basin which is interpreted as a back-arc basin that formed as a result of the counter-clockwise rotation of Corsica-Sardinia micro-plate during the Miocene [Réhault et al., 1984; Gorini, 1993; Gueguen et al., 1998; Carminati et al., 1998a and 1998b; Gattacceca et al., 2007]. Few attention has been paid on the marine geology of this transitional area between Gulf of Lion and Ligurian margins, and very few published interpretations of seismic and core data are available [Leenhardt et al., 1969; Ducrot, 1967; Froget, 1967, 1971, 1972, 1974], in contrast to the Gulf of Lion margin [e.g. Gorini, 1993; Guennoc et al., 2000, Séranne, 1999; Lofi et al., 2003, 2005; Lofi and Berné 2008; Bache et al., 2010; Oudet et al., 2010; Moulin et al., 2015] and the Ligurian margin [e.g. Rollet, 1999; Rollet et al., 2002; Bigot-Cormier et al., 2004; Larroque et al., 2010; Sage et al., 2011]. The tectonic style of the Gulf of Lion margin differs significantly from that of the Ligurian margin since the latter was strongly influenced by post-rift tectonic inversion [Bigot-Cormier et al., 2004; Sage et al., 2011]. The occurrence of extensive oligo-miocene and plio-quaternary deposits on the Provence continental shelf [Oudet et al., 2010; Tassy et al., 2014] provides a good opportunity to evidence and characterize the syn-rift and post-rift deformation at the transition between the Gulf of Lion and Ligurian margins.

On the basis of an integrated seismic, rock sample and field study, the present work aims at 1) constructing a tectono-stratigraphic framework for the Provence continental shelf by defining and interpreting the main seismo-stratigraphic units and remarkable surfaces, 2) mapping and characterizing the main structural domains, 3) providing new insights into the Mesozoic and Cenozoic paleogeography of Provence, and 4) characterizing the syn-rift and post-rift deformation of the Provence margin.

\section{GEODYNAMIC HISTORY OF PROVENCE}

During the rifting of the Liguro-Piemontais domain (Middle Triassic to Late Jurassic), the Provence area was located on a NE-trending margin of the Alpine Tethys [e.g. Stampfli and Borel, 2002]. The extensional regime related to the opening of the Liguro-Piemontais ocean continued during the Early Cretaceous, thus resulting in the development of thick carbonate platform deposits in Provence [e.g. De Graciansky and Lemoine, 1988; Masse et al., 2009]. During the latest Barremian-earliest Aptian, the carbonate platforms drowned in southern Provence as a result of the development of a subsiding basin. During the mid-Cretaceous (Albian-Lower Cenomanian), the formation of the Durance high [Gignoux, 1925; Masse and Philip, 1976] resulted in the subaerial exposure of the Provence area and the development of a major regional unconformity. During the Cenomanian to the Santonian, a rather shallow ( $200 \mathrm{~m}$ water-depth), east-west trending, narrow and elongated basin was formed (South Provence basin) in a transtensive regime that prevailed mainly during the Turonian-Coniacian [Floquet and Hennuy, 2003; Hennuy, 2003; Floquet et al.,
2005, 2006; Reijmer et al., 2015]. The South Provence basin was bordered to the north by an extensive carbonate platform and to the south by an emerged crystalline massif [Philip, 1970; Hennuy, 2003].

At the end of the Cretaceous (late Santonian), the convergence between Europe and Iberia was initiated [e.g. Dercourt et al., 1986; Stampfli and Borel, 2002] and led to the development of the Pyrenean fold-and-thrust belt [e.g. Mattauer, 1968; Roure and Choukroune, 1998; Bestani et al., 2015]. In Provence, a thick continental succession $(\sim 1200 \mathrm{~m}$ at the depocentre of the Arc basin), of late Santonian to Lutetian age, deposited in a foreland setting [Leleu et al., 2009]. During the Late Eocene (Bartonian) a major phase of shortening occurred with north-verging fold and thrust development, overprinting the former stuctures [e.g. Lutaud, 1935; Guieu, 1968; Tempier, 1987; Lacombe and Jolivet, 2005].

During the latest Eocene and Early Oligocene, the E-W extension in the West-European platform led to the formation of the West-European rift system [Bergerat, 1987; Hippolyte et al., 1991; Ziegler, 1994; Séranne, 1999]. During the Late Oligocene a second extensional phase was initiated as a result of the opening of the Liguro-Provençal back-arc basin [Rehault et al., 1984; Hippolyte et al., 1993; Mauffret and Gorini, 1996; Mauffret et al., 2004; Gattacceca et al., 2007; Jolivet et al., 2015]. The opening of the Liguro-Provençal basin occurred in two steps: a syn-rift stage (Chattian to early Burdigalian: 30-20.5 Ma) and a post-rift stage (early Burdigalian-Langhian: 20.5-15 Ma) with oceanic crust accretion and associated anticlockwise rotation of the CorsicaSardinia continental block [e.g. Gattacceca et al., 2007]. Oligocene-Early Miocene extensional phases were responsible for the reactivation of NNE-trending faults such as the Aix-en-Provence fault system and for the formation of grabens such as the Marseille, Huveaune and Aix-en-Provence basins that are filled with thick (locally higher than $800 \mathrm{~m}$ ), continental to shallow-marine successions [e.g. Nury, 1988; Hippolyte et al., 1993] (fig. 1B).

In South-East France, the Alpine front propagated toward the SW, from the Late Oligocene to the Middle Miocene, thus leading to the reactivation of Pyrenean structures.

The onset of a compressive regime in Provence [Villeger, 1984; Villeger and Andrieux, 1987; Blès and Gros, 1991] is recorded from the Early Miocene, but its timing with regards to the end of the oceanic accretion in the Liguro-Provençal basin is still unclear. In northern Provence, the main Miocene Alpine fold-and-thrust deformation occurred during the Tortonian [Clauzon, 1984]. In southern Provence, evidences of post-rift deformation are scattered: 1) vertical movements (uplifts) that are recorded by sea-level markers such as Miocene marine abrasion surfaces [Champion et al., 2000] and Pliocene shelf breaks [Tassy, 2012], and 2) major regional faults that are considered to be active during post-oligocene times such as the Salon Cavaillon fault [Molliex et al., 2011] and the Aix fault [Guignard et al., 2005] (fig 1B).

The morphology of the continental margins in the whole Mediterranean domain has been strongly affected by the so-called Messinian Salinity Crisis (MSC) that relates to a major and rapid sea-level drop that induced the development of a spectacular subaerial erosional surface (MES: Messinian Erosional Surface) [Hsü et al., 1973; Krijgsman et al., 1999; Manzi et al., 2013; Roveri et al., 2014 and references therein]. 


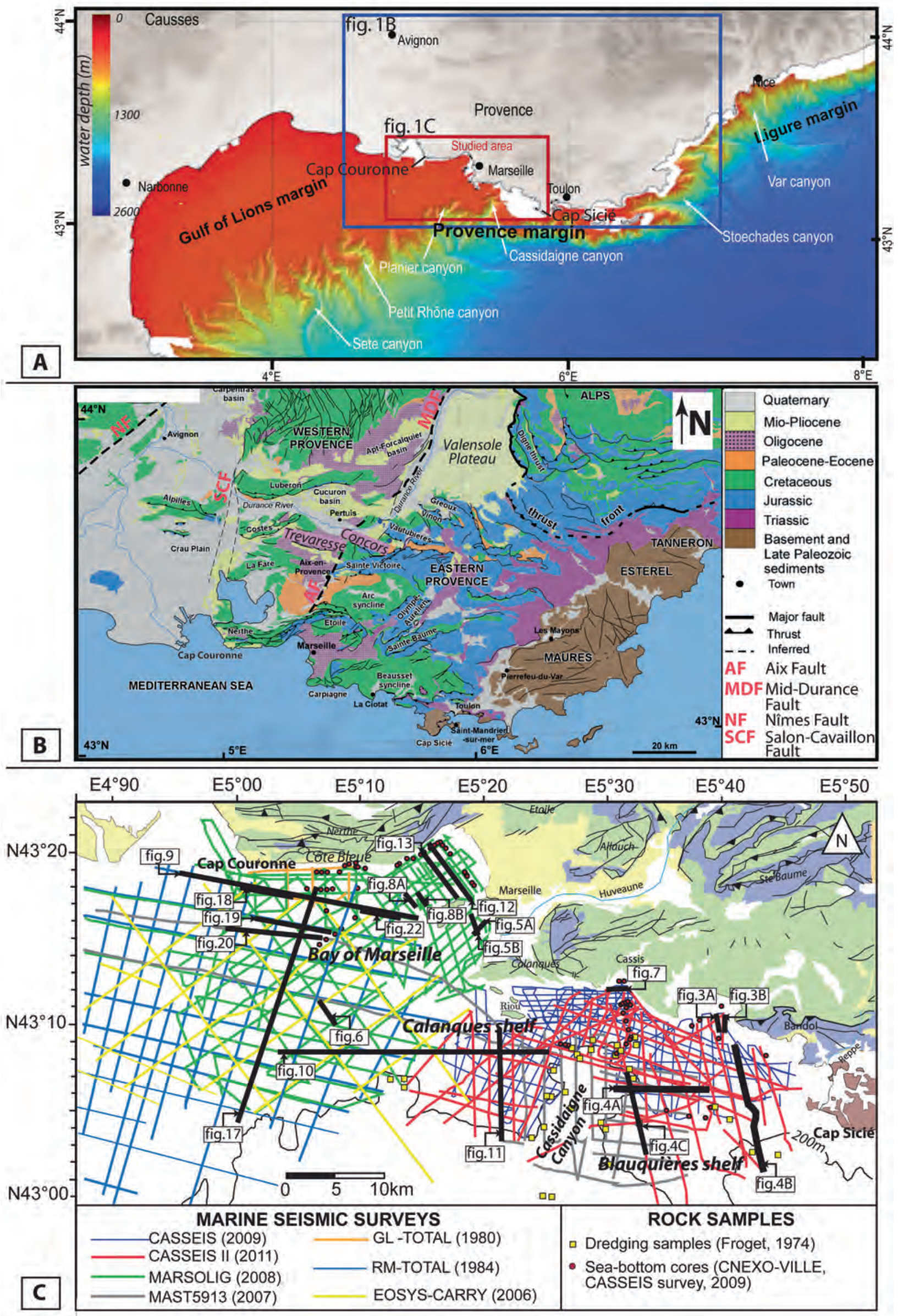

FIG. 1. - A) Bathymetric map of the Gulf of Lion, Provence and Ligurian margin (source: SHOM, IFREMER), B) Geological and structural setting of Provence, modified after Bestani et al. [2015], C) Location of the marine seismic profiles and cores and simplified onshore geological map. 


\section{PREVIOUS MARINE GEOLOGY STUDIES OFFSHORE PROVENCE}

In contrast to the neighbouring Gulf of Lion and Ligurian margins, few marine geology studies have focused on the Provence continental shelf and published seismic and core data are scarce. The first dredging of submarine outcrops from the Provence continental shelf has been carried on during the late 1940s around the Cassidaigne canyon [Bourcart, 1949] and yielded Palaeozoic metamorphic rocks within the canyon and Mesozoic dolomites and marls in the canyon's head. New dredging surveys of the Provence continental shelf, performed by the Cousteau submarine saucer in the early 1960s, provided a significant pre-Pliocene submarine rock database from the Cassidaigne canyon and Blauquières shelf [Blanc and Blanc-Vernet, 1966; Blanc et al., 1967; Froget, 1971; Froget, 1974]. Plio-Quaternary deposits of the Provence continental shelf have been studied with sedimentological [e.g. Blanc and Blanc-Vernet, 1966], diagenetical [Froget et al., 1972] and micropaleontological approaches [Blanc-Vernet, 1969]. A detailed geomorphologic study of the Provence continental slope has been conducted by Bourcart [1960] who identified and mapped the main submarine canyons. On the Provence continental shelf, later geomorphologic studies have evidenced the presence of extensive underwater notches at various water depths [Collina-Girard, 1992; 1997].

The first reflexion seismic survey on the Provence continental shelf has been performed in 1965 by the Oceanographic Museum of Monaco, using sparker seismic source, between the Planier islands and the Cassidaigne canyon. The results have been published by Leenhardt et al. [1969] who evidenced NE-SW anticlines and synclines south of Riou island as well as various small-scale paleo-canyons incising the edge of the continental shelf and filled with sediment. Other sparker seismic profiles have been performed on the Banc des Blauquières, east of the Cassidaigne canyon and studied by Froget [1974] who evidenced the occurrence of a thick interval of deposits characterized by a layered seismic facies, crosscutting the Palaeozoic basement, that was interpreted as representing the sedimentary infill of a graben. During the 1980s, various oil exploration 2D seismic databases have been acquired in the Gulf of Lion. Most of the profiles are located in the continental slope or deep-water area, but some of them reach the continental shelf. Maps and paleogeographic reconstructions of the Oligo-Miocene and Plio-Quaternary deposits of the offshore Provence area have been performed from the stratigraphic interpretation of air-gun oil industry seismic profiles [Bache, 2008; Oudet, 2008; Oudet et al., 2010]. The recent acquisition of sparker and airgun seismic profiles offshore Provence (MARSOLIG-2008, CASSEIS2009 and CASSEIS-2011 surveys) led to the revision of the interpretations by Froget [1974] regarding the Blauquières grabens. Tassy [2012] and Tassy et al. [2014] regarded such structures as steep flanked canyons formed during the Messinian and filled with Plio-Quaternary deposits.

\section{DATABASE AND METHODS}

The present study focuses on the Provence continental shelf located between Cap Couronne and Cap Sicié. The dataset used in this study includes marine seismic reflection 2D profiles (fig. 1), rock samples extracted from seabed and coastal outcrops. The present study is mainly based on newly acquired marine seismic data from 5 surveys performed on board the R/V TETHYS II vessel: MAST5913 (2007 and 2009), MARSOLIG (2008), CASSEIS (2009) and CASSEIS II (2011). The seismic profiles cover an area of approximately $1800 \mathrm{~km}^{2}$ with a total survey length of $2740 \mathrm{~km}$ and an average profile spacing of $1 \mathrm{~km}$. Seismic profiles consists of 255 high resolution (HR) and very high resolution (VHR) sections with a recording length ranging from $0.2 \mathrm{~s}$ to $2 \mathrm{~s}$ two-way-travel-time (TWTT). The seismic acquisition devices used for these seismic surveys are displayed in table I. In addition, older industrial and academic seismic surveys were integrated in this study [e.g. Gorini, 1993; Dos Reis, 2001; Lofi et al., 2003; Oudet et al., 2010]: GL80 (TOTAL), RM84 (TOTAL), MARION (IFREMER), CALMAR-99 (IFREMER) and Carry (EOSYS). Paper seismic profiles from Leenhardt et al. [1969] were used for geological interpretations but were not integrated in the digital dataset.

TABLE I - Summary of seismic databases used in the present paper

\begin{tabular}{lcll} 
Seismic survey & year & Seismic source & Streamer \\
\hline LM5913-2007 & 2007 & Air gun & Multitrace (6 traces) \\
\hline $\begin{array}{l}\text { MARSOLIG } \\
\text { dx.doi.org/10.17600/8450170 }\end{array}$ & 2008 & $\begin{array}{l}\text { Sparker 1000J } \\
\text { Sparker 50J }\end{array}$ & $\begin{array}{l}\text { Multitrace (6 traces) } \\
\text { Monotrace }\end{array}$ \\
\hline $\begin{array}{l}\text { CASSEIS } \\
\text { dx.doi.org/10.17600/9450130 }\end{array}$ & 2009 & Air gun & Multitrace (12 traces) \\
\hline $\begin{array}{l}\text { LM5913-2009 } \\
\begin{array}{l}\text { CASSEIS II } \\
\text { dx.doi.org/10.17600/11450110 }\end{array}\end{array}$ & 2011 & Sparker 1000J & Multitrace (12 traces) \\
\hline
\end{tabular}

The present study integrates descriptions of rock samples dredged from seabed and published by Froget [1967, 1972, and 1974] as well as newly acquired samples collected with the CNEXO-VILLE rock corer (BRGM) during the CASSEIS survey and published by Tassy et al. [2014]. The location and description of the seabed rock samples are summarized in table II.

The seismic interpretation is based on (1) the identification of major seismic horizons and major faults over the surveyed area and imaged by a maximum of cross-cutting lines and (2) the definition of seismic units that are bounded by extensively correlatable seismic reflectors or envelopes of seismic terminations and that are characterized by a given seismic facies. Seismic facies are defined by a set of seismic attributes such as reflector continuity, amplitude and frequency. The lack of offshore wells within the Provence continental shelf did not allow direct lithologic and chronostratigraphic calibration of the seismic strata to be performed. The chrono-stratigraphic interpretation of the seismic unconformities and units are based on 1) the interpretation of seismic facies in terms of lithology and small-scale (meter to decameter-scale) heterogeneity distribution, 2) the comparison between the seismic stratigraphic patterns evidenced from profiles offshore and the regional 
TABLE II - Sea-bottom cores collected during the CASSEIS survey (2009)

\begin{tabular}{|c|c|c|c|c|c|}
\hline CORE NAME & $\mathbf{X}$ & $\mathbf{Y}$ & $\begin{array}{l}\text { Water } \\
\text { depth } \\
(\mathrm{m})\end{array}$ & CORE DESCRIPTION & AGE \\
\hline CR01 & $43^{\circ} 17,972$ & $5^{\circ} 20,276$ & 39,3 & Clay with red algal crusts & Quaternary \\
\hline CR01b & $43^{\circ} 17,974$ & $5^{\circ} 20,302$ & 38,9 & Clay with bioclasts and rock fragments & Quaternary \\
\hline CR02 & $43^{\circ} 18,112$ & $5^{\circ} 20,158$ & 40,4 & Fine-grained sandstone & Quaternary \\
\hline CR03 & $43^{\circ} 18,426$ & $5^{\circ} 19,865$ & 42,5 & Argilaceous medium to coarse-grained sandstone & Quaternary \\
\hline CR03b & $43^{\circ} 18,432$ & $5^{\circ} 19,868$ & 45 & Clay with bioclasts (Bryozoans, Mollusks) & Quaternary \\
\hline CR04 & $43^{\circ} 18,563$ & $5^{\circ} 19,737$ & 49 & Clay with rock fragments & Quaternary \\
\hline CR05 & $43^{\circ} 18,728$ & $5^{\circ} 19,593$ & 55 & Ferruginized conglomerate & Quaternary \\
\hline CR06 & $43^{\circ} 19,904$ & $5^{\circ} 18,474$ & 59,2 & $\begin{array}{l}\text { Peloidal packstone with fresh-water gastropod molds } \\
\text { (lacustrine limestone) }\end{array}$ & Oligocene \\
\hline CR06b & $43^{\circ} 19,885$ & $5^{\circ} 18,493$ & 59 & Lacustrine limestone with gastropods & Oligocene \\
\hline CR07 & $43^{\circ} 20,244$ & $5^{\circ} 18,113$ & 55,2 & $\begin{array}{l}\text { Medium-to-coarse-grained sandstone with angular } \\
\text { quartz grain, calcite sparry cement }\end{array}$ & $?$ \\
\hline CR08 & $43^{\circ} 20,412$ & $5^{\circ} 17,921$ & 52,2 & Clay & Quaternary \\
\hline CR09 & $43^{\circ} 20,652$ & $5^{\circ} 17,695$ & 42,7 & Argilaceous sand with shell fragments & Quaternary \\
\hline CR10 & $43^{\circ} 20,539$ & $5^{\circ} 17,417$ & 51,2 & Argilaceous sand with pebbles & Quaternary \\
\hline CR11 & $43^{\circ} 20,438$ & $5^{\circ} 17,167$ & 44,2 & Argilaceous sand with shell fragments & Quaternary \\
\hline CR12 & $43^{\circ} 20,272$ & $5^{\circ} 16,827$ & 47,5 & Argilaceous sand & Quaternary \\
\hline CR13 & $43^{\circ} 20,095$ & $5^{\circ} 16,411$ & 52,5 & Clay & $?$ \\
\hline CR14 & $43^{\circ} 19,962$ & $5^{\circ} 16,138$ & 50,5 & Bioclastic sand, coralline crust, serpules & Quaternary \\
\hline CR14b & $43^{\circ} 19,958$ & $5^{\circ} 16,135$ & 51 & Marls and bioclastic sand, coralline crust, serpules & Quaternary \\
\hline CR15 & $43^{\circ} 19,926$ & $5^{\circ} 16,061$ & 51,5 & Sandy Clay & Quaternary \\
\hline CR16 & $43^{\circ} 19,594$ & $5^{\circ} 15,343$ & 62 & Clay & Quaternary \\
\hline CR17 & $43^{\circ} 19,147$ & $5^{\circ} 14,293$ & 68 & $\begin{array}{c}\text { Packstone with Foraminifers (miliolids), Scleractinian, } \\
\text { Mollusks and Echinoderms }\end{array}$ & $\begin{array}{l}\text { Oligo- } \\
\text { Miocene }\end{array}$ \\
\hline CR18 & $43^{\circ} 19,555$ & $5^{\circ} 14,654$ & 54,5 & $\begin{array}{l}\text { Carbonate mudstone with ostracods, gastropods, } \\
\text { coated grains, circumgranular cracks (palustrine } \\
\text { limestone) }\end{array}$ & Oligocene \\
\hline CR19 & $43^{\circ} 19,33$ & $5^{\circ} 14,315$ & 60,7 & $\begin{array}{c}\text { Carbonate breccia with micritic elements (pedogenic } \\
\text { breccia?) }\end{array}$ & Oligocene \\
\hline CR21 & $43^{\circ} 19,383$ & $5^{\circ} 10,535$ & 20,5 & $\begin{array}{l}\text { Conglomerate with rounded pebbles and sparry } \\
\text { cements }\end{array}$ & Oligocene? \\
\hline CR22 & $43^{\circ} 19,111$ & $5^{\circ} 10,989$ & 40,7 & Clay with rock fragments & Quaternary \\
\hline CR22b & $43^{\circ} 19,109$ & $5^{\circ} 11,989$ & 40,2 & Clay with shell fragments & Quaternary \\
\hline CR23 & $43^{\circ} 19,091$ & $5^{\circ} 10,676$ & 38 & Clay with shell fragments & Quaternary \\
\hline CR24 & $43^{\circ} 19,079$ & $5^{\circ} 9,938$ & 25 & Clay with red algae, bryozoans, mollusks, serpules & Quaternary \\
\hline CR24b & $43^{\circ} 19,078$ & $5^{\circ} 9,951$ & 31,7 & red algal and oyster limestone & $\begin{array}{c}\text { Oligo- } \\
\text { Miocene? }\end{array}$ \\
\hline CR25 & $43^{\circ} 19,081$ & $5^{\circ} 9,819$ & 24,2 & Recrystallized (calcitized) coral & $\begin{array}{c}\text { Oligo- } \\
\text { Miocene? }\end{array}$ \\
\hline CR26 & $43^{\circ} 18,692$ & $5^{\circ} 9,492$ & 29 & Argilaceous bioclastic sand & Quaternary \\
\hline CR26b & $43^{\circ} 18,701$ & $5^{\circ} 9,489$ & 26,5 & red algae and shell fragments & Quaternary \\
\hline CR27 & $43^{\circ} 18,684$ & $5^{\circ} 8,363$ & 27 & red algae and shell fragments & Quaternary \\
\hline CR27b & $43^{\circ} 18,701$ & $5^{\circ} 7,956$ & 33,5 & red algae & Quaternary \\
\hline CR28 & $43^{\circ} 18,704$ & $5^{\circ} 7,477$ & 40,7 & Clay with shell fragments & Quaternary \\
\hline CR29 & $43^{\circ} 17,98$ & $5^{\circ} 8,386$ & 54,2 & $\begin{array}{l}\text { Fine-to-medium-grained sandstone with angular } \\
\text { quartz grain, calcite sparry cement }\end{array}$ & $?$ \\
\hline CR29b & $43^{\circ} 17,975$ & $5^{\circ} 8,392$ & 54,7 & $\begin{array}{l}\text { Medium-grained sandstone, limestone pebbles with } \\
\text { perforations }\end{array}$ & $?$ \\
\hline CR30 & $43^{\circ} 17,968$ & $5^{\circ} 8,848$ & 57,5 & Clay with mollusks and red algal fragments & Quaternary \\
\hline CR30b & $43^{\circ} 17,971$ & $5^{\circ} 8,815$ & 53,7 & Clay with Spondyle fragments & Quaternary \\
\hline CR31 & $43^{\circ} 17,982$ & $5^{\circ} 7,818$ & 53 & $\begin{array}{l}\text { Medium-grained sandstone with angular quartz grain, } \\
\text { calcite sparry cement, miliolids }\end{array}$ & $?$ \\
\hline CR32 & $43^{\circ} 17,996$ & $5^{\circ} 6,658$ & 62,7 & algual mud & Quaternary \\
\hline CR33 & $43^{\circ} 16,716$ & $5^{\circ} 8,488$ & 68,2 & $\begin{array}{l}\text { Medium-grained sandstone with angular quartz grain, } \\
\text { calcite sparry cement, miliolids }\end{array}$ & $?$ \\
\hline CR34 & $43^{\circ} 17,888$ & $5^{\circ} 11,029$ & 54,5 & algal sand & Quaternary \\
\hline CR35 & $43^{\circ} 15,978$ & $5^{\circ} 10,263$ & 71,7 & Quartzose calcarenite & $?$ \\
\hline CR36 & $43^{\circ} 15,552$ & $5^{\circ} 9,496$ & 73,5 & Quartzose calcarenite with benthic forams & $\begin{array}{l}\text { Oligo- } \\
\text { Miocene }\end{array}$ \\
\hline CR37 & $43^{\circ} 15,187$ & $5^{\circ} 8,835$ & 83,5 & $\begin{array}{c}\text { Quartzose calcarenite with benthic forams, } \\
\text { echinoderms (echinoids, holothurians) } \\
\text { leached/recrystalized mollusks. }\end{array}$ & $\begin{array}{l}\text { Oligo- } \\
\text { Miocene }\end{array}$ \\
\hline CR38 & $43^{\circ} 14,883$ & $5^{\circ} 8,265$ & 88,2 & $\begin{array}{l}\text { Fine-grained glauconitic sandstone with sparry } \\
\text { cements; }\end{array}$ & $?$ \\
\hline CR39 & $43^{\circ} 14,67$ & $5^{\circ} 7,873$ & 88,2 & $\begin{array}{c}\text { Fine-grained glauconitic sandstone with sparry } \\
\text { cements. }\end{array}$ & $?$ \\
\hline CR39b & $43^{\circ} 14,668$ & $5^{\circ} 7,869$ & 88 & $\begin{array}{l}\text { Laminated silty clay with forams and strongly } \\
\text { compacted sandstone with calcitic sparry cement. }\end{array}$ & $?$ \\
\hline CR40 & $43^{\circ} 3,825$ & $5^{\circ} 38,785$ & 97 & Phyllad & Paleozoic \\
\hline CR41 & $43^{\circ} 3,325$ & $5^{\circ} 38,277$ & 93,2 & Phyllad & Paleozoic \\
\hline CR42 & $43^{\circ} 3,503$ & $5^{\circ} 36,973$ & 112 & Phyllad & Paleozoic \\
\hline CR43 & $43^{\circ} 3,883$ & $5^{\circ} 35,213$ & 127 & Phyllad & Paleozoic \\
\hline CR44 & $43^{\circ} 7,9391$ & $5^{\circ} 27,427$ & 320 & Clay & Quaternary \\
\hline CR45 & $43^{\circ} 7,976$ & $5^{\circ} 27,343$ & 290 & Clay & Quaternary \\
\hline CR46 & $43^{\circ} 7,986$ & $5^{\circ} 27,216$ & 246 & Clay & Quaternary \\
\hline CR47 & $43^{\circ} 8,034$ & $5^{\circ} 26,987$ & 148 & Clay & Quaternary \\
\hline CR48 & $43^{\circ} 7,243$ & $5^{\circ} 31$ & 281 & Bioclastic sand & Quaternary \\
\hline CR49b & $43^{\circ} 7,343$ & $5^{\circ} 31,352$ & 123,2 & Sparitic limestone & $?$ \\
\hline CR50 & $43^{\circ} 8,067$ & $5^{\circ} 32,433$ & 40 & Red algal sand & Quaternary \\
\hline
\end{tabular}


TABLE II - follow

\begin{tabular}{|c|c|c|c|c|c|}
\hline CORE NAME & $\mathbf{x}$ & $\mathbf{Y}$ & $\begin{array}{l}\text { Water } \\
\text { depth }\end{array}$ & CORE DESCRIPTION & AGE \\
\hline CR51 & $43^{\circ} 7,821$ & $5^{\circ} 32,104$ & 83,2 & $\begin{array}{c}\text { Carbonate sand with red algae, mollusks, bryozoan } \\
\text { and solitary corals }\end{array}$ & Quaternary \\
\hline CR52 & $43^{\circ} 8,194$ & $5^{\circ} 32,515$ & 37,2 & $\begin{array}{l}\text { Carbonate sand with red algae, mollusks, bryozoan } \\
\text { and solitary corals }\end{array}$ & Quaternary \\
\hline CR54 & $43^{\circ} 8,834$ & $5^{\circ} 32,424$ & 70 & Bioclastic sand & Quaternary \\
\hline CR55 & $43^{\circ} 8,83$ & $5^{\circ} 32,372$ & 75 & Bioclastic sand & Quaternary \\
\hline CR57 & $43^{\circ} 11,823$ & $5^{\circ} 31,752$ & 48 & Bioclastic sand & Quaternary \\
\hline CR57b & $43^{\circ} 11,785$ & $5^{\circ} 31,762$ & 51 & $\begin{array}{c}\text { Echinoderm, Red algal and foraminiferal ( Hedbergella, } \\
\text { Rotalipora) glauconitic packstone. }\end{array}$ & Cenomanian \\
\hline CR58 & $43^{\circ} 11,82$ & $5^{\circ} 32,204$ & 48 & Sandy clay & Quaternary \\
\hline CR59 & $43^{\circ} 10,498$ & $5^{\circ} 32,331$ & 78 & Sand & Quaternary \\
\hline CR59b & $43^{\circ} 10,496$ & $5^{\circ} 32,297$ & 81 & Sand & Quaternary \\
\hline CR60 & $43^{\circ} 10,485$ & $5^{\circ} 32,208$ & 80 & Siliceous spiculite. & $\begin{array}{l}\text { Aptian- } \\
\text { Albian }\end{array}$ \\
\hline CR61 & $43^{\circ} 10,364$ & $5^{\circ} 31,889$ & 81 & Bioclastic sand & Quaternary \\
\hline CR62 & $43^{\circ} 10,377$ & $5^{\circ} 31,897$ & 80 & Qz calcarenite with sponge spicules. & Cretaceous? \\
\hline CR63 & $43^{\circ} 10,351$ & $5^{\circ} 31,837$ & 82 & Bioclastic sand & Quaternary \\
\hline CR64 & $43^{\circ} 10,321$ & $5^{\circ} 31,664$ & 85 & Quartzite & $?$ \\
\hline CR65 & $43^{\circ} 10,125$ & $5^{\circ} 32,207$ & 79 & $\begin{array}{c}\text { Foraminiferal peloidal Packstone Grainstone with } \\
\text { orbitolinids and miliolids }\end{array}$ & $\begin{array}{c}\text { Lower } \\
\text { Cretaceous }\end{array}$ \\
\hline CR65b & $43^{\circ} 10,142$ & $5^{\circ} 32,177$ & 79 & Microbial bindstone & $?$ \\
\hline CR67 & $43^{\circ} 10,214$ & $5^{\circ} 32,403$ & 69,6 & Bioclastic sandy clay & Quaternary \\
\hline CR68 & $43^{\circ} 9,846$ & $5^{\circ} 32,066$ & 85 & Bioclastic sand & Quaternary \\
\hline CR70 & $43^{\circ} 9,004$ & $5^{\circ} 37,32$ & 67 & Qz calcarenite with sponge spicula, forams. & $?$ \\
\hline CR71 & $43^{\circ} 9,256$ & $5^{\circ} 38,233$ & 68 & Fine-grained $\mathrm{Qz}$ sand & Quaternary \\
\hline CR72 & $43^{\circ} 10$ & $5^{\circ} 39,906$ & 43,2 & Fine-grained $\mathrm{Qz}$ sand with shell fragments & Quaternary \\
\hline CR73 & $43^{\circ} 8,109$ & $5^{\circ} 39,428$ & 88 & Fine-grained Qz Sand & Quaternary \\
\hline CR74 & $43^{\circ} 6,829$ & $5^{\circ} 43,297$ & 59 & $\begin{array}{l}\text { Conglomerate with tighlty cemented glauconitic } \\
\text { sandstone matrix and rounded limestone pebbles }\end{array}$ & Pliocene? \\
\hline CR74b & $43^{\circ} 6,829$ & $5^{\circ} 43,297$ & 59 & $\begin{array}{l}\text { Conglomerate with tighlty cemented glauconitic } \\
\text { sandstone matrix and rounded limestone pebbles }\end{array}$ & Pliocene? \\
\hline
\end{tabular}

stratigraphic architecture onshore and 3) the dating of sea-bottom rock samples located on seismic profiles. Ages for sea-bottom rock samples have been determined by using benthic foraminiferal biostratigraphy or, when relevant microfossils were lacking, by lithologic and faciologic analogies with onshore regional outcrops.

\section{RESULTS}

\section{Definition of seismic units and chronostratigraphic interpretation}

The interpretation of seismic profiles and the analysis of rock samples collected on the sea-bottom allowed seven

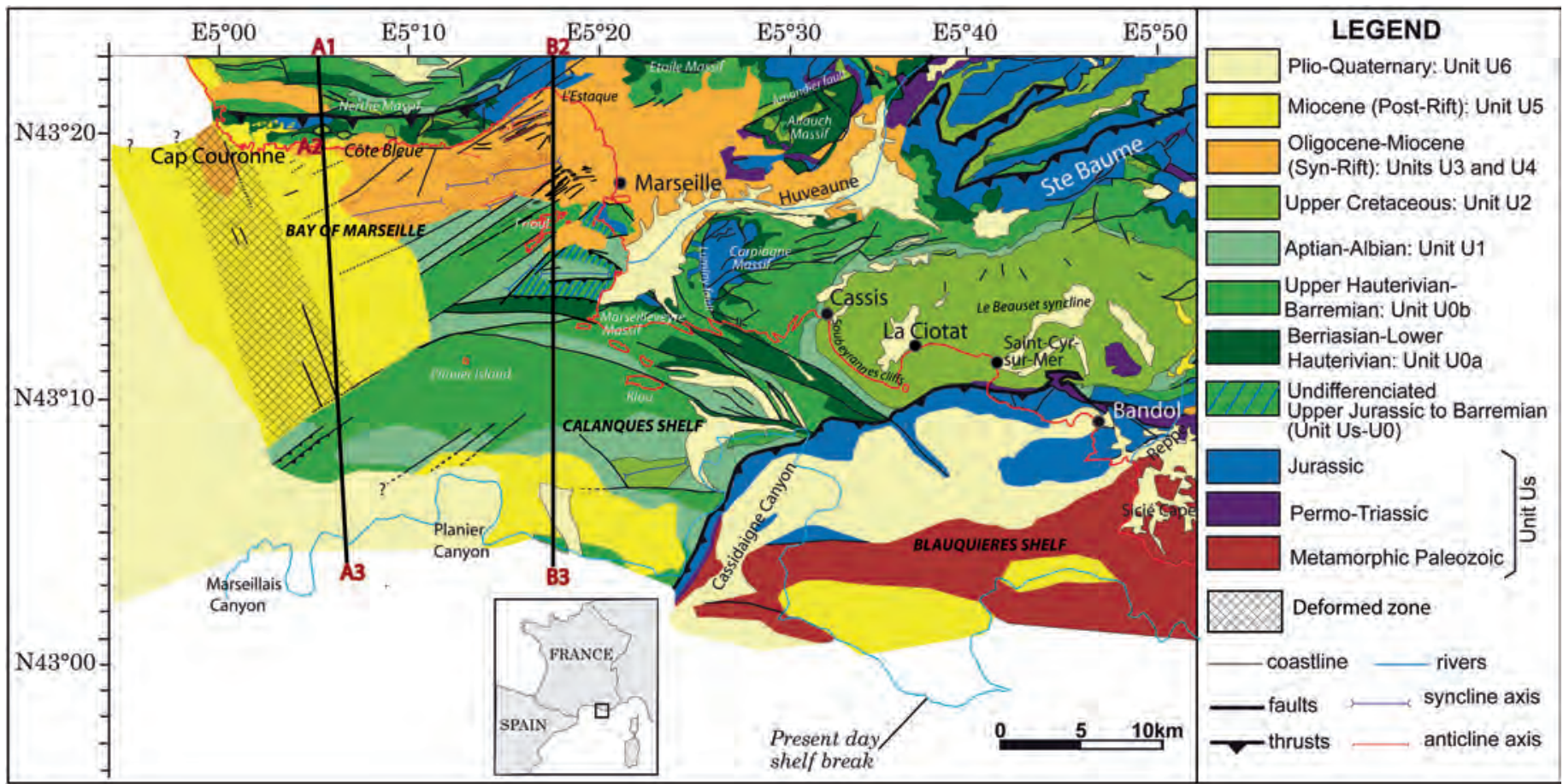

FIG. 2. - Geological map of onshore southern Provence, modified after the BRGM geological map of Marseille 1/250,000 [Rouire and Blanc, 1979] and offshore Provence continental shelf (this study). Plio-Quaternary deposits (Unit 6) are mapped when its two-way time thickness is higher than 100 ms (two-way time). 
post-Jurassic seismo-stratigraphic units to be identified and mapped across the Provence continental shelf (fig. 2). The acoustic basement (Us) is characterized by an unstructured seismic facies ranging from chaotic to transparent. It correlates with the Paleozoic metamorphic basement (samples CR40, CR41, CR42, CR43: table II; samples m1, m2, m3, m4: table III), the late Paleozoic (Carboniferous and Permian: sample p1, table III) deposits and part of the Mesozoic (Triassic to Jurassic: samples d2, d2, d3, d4, table III) sedimentary cover (fig. 3 and 4).

\section{Unit UO (Berriasian to Barremian).}

The U0 unit was distinguished from the underlying Us unit only on sparker profiles, where it exhibits in its lower part a set of tectonically deformed and poorly continuous reflectors (fig. 5). This stratified interval (U0a) is interpreted to represent Berriasian to Hauterivian limestone and argillaceous limestones. The sea-bottom sample v1 (table III) collected within this stratified seismic facies interval yelded a lower Valanginian age [Froget, 1974]. The upper part of the

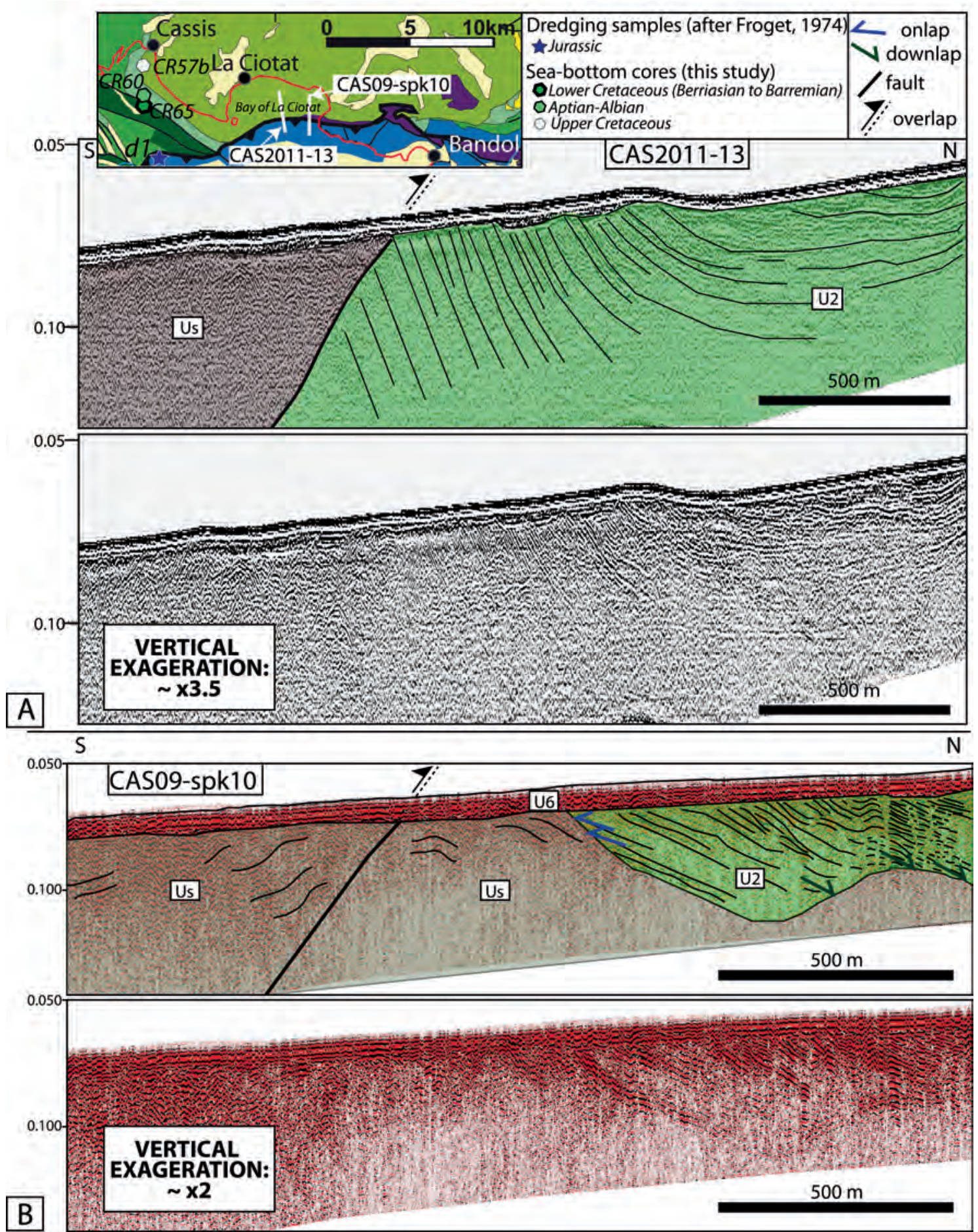

FIG. 3. - VHR sparker seismic images and interpretation of profiles A) CAS2011-13 and B) CAS09-spk10, both located in the bay of La Ciotat (see location in fig. 1). Us: acoustic basement (pre-Cretaceous); U2: Upper Cretaceous; U6: Plio-Quaternary. 

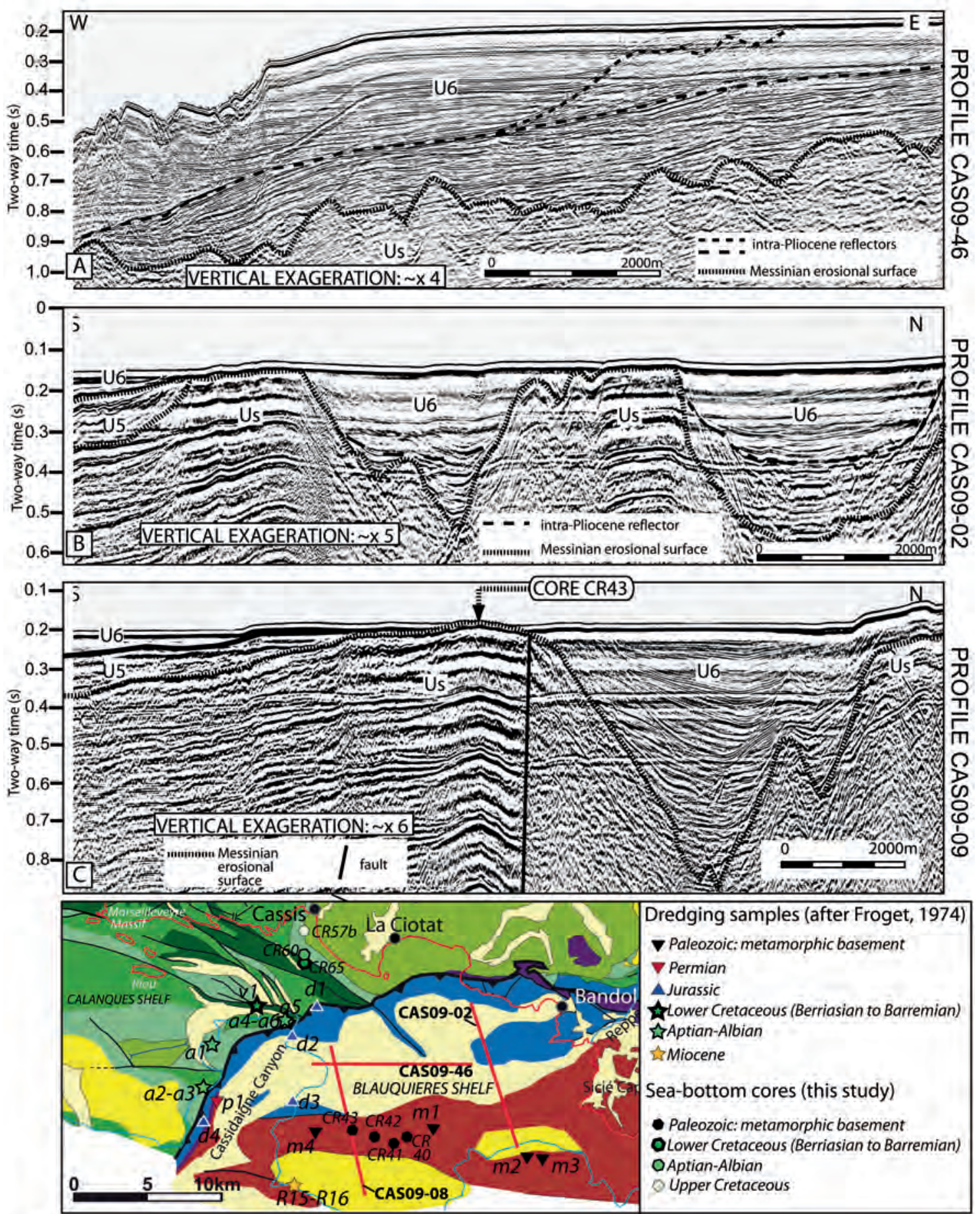

FIG. 4. - HR airgun seismic images and interpretation of profiles A) CAS09-46 and B) CAS09-02, both located in the Blauquières shelf (see location in fig. 1). Us: acoustic basement (pre-Cretaceous); U6: Plio-Quaternary.

unit exhibits generally a non-stratified seismic facies (U0b) and likely correlate with the Upper Hauterivian and Barremian massive limestones and dolomites (fig. 6 and 7). On airgun profiles, the U0 unit exhibits a chaotic facies that cannot be distinguished from the underlying Us unit. Onshore, the thickness of Berriasian to Barremian deposits may reach $750 \mathrm{~m}$ in the Marseille area whereas offshore the two-way time thickness of the U0 unit is higher than $0.2 \mathrm{~s}$ (approximately $600 \mathrm{~m}$ by considering a velocity of $6000 \mathrm{~m} / \mathrm{s}$ in Urgonian tight limestones after Fournier et al. [2011]).

\section{Unit U1 (Aptian-Albian)}

The unit U1 was identified on both sparker and air-gun profiles as being composed of a well stratified seismic facies with low-frequency, continuous, parallel and folded reflectors (fig. 5, 7, 8, 9, 10 and 11). An upward transition in seismic facies, from chaotic to layered, is commonly observed between U0 and U1 units (fig. 7). An Aptian to Albian age was assigned to this seismic unit based on the following three criteria: 1) samples dredged from this unit 

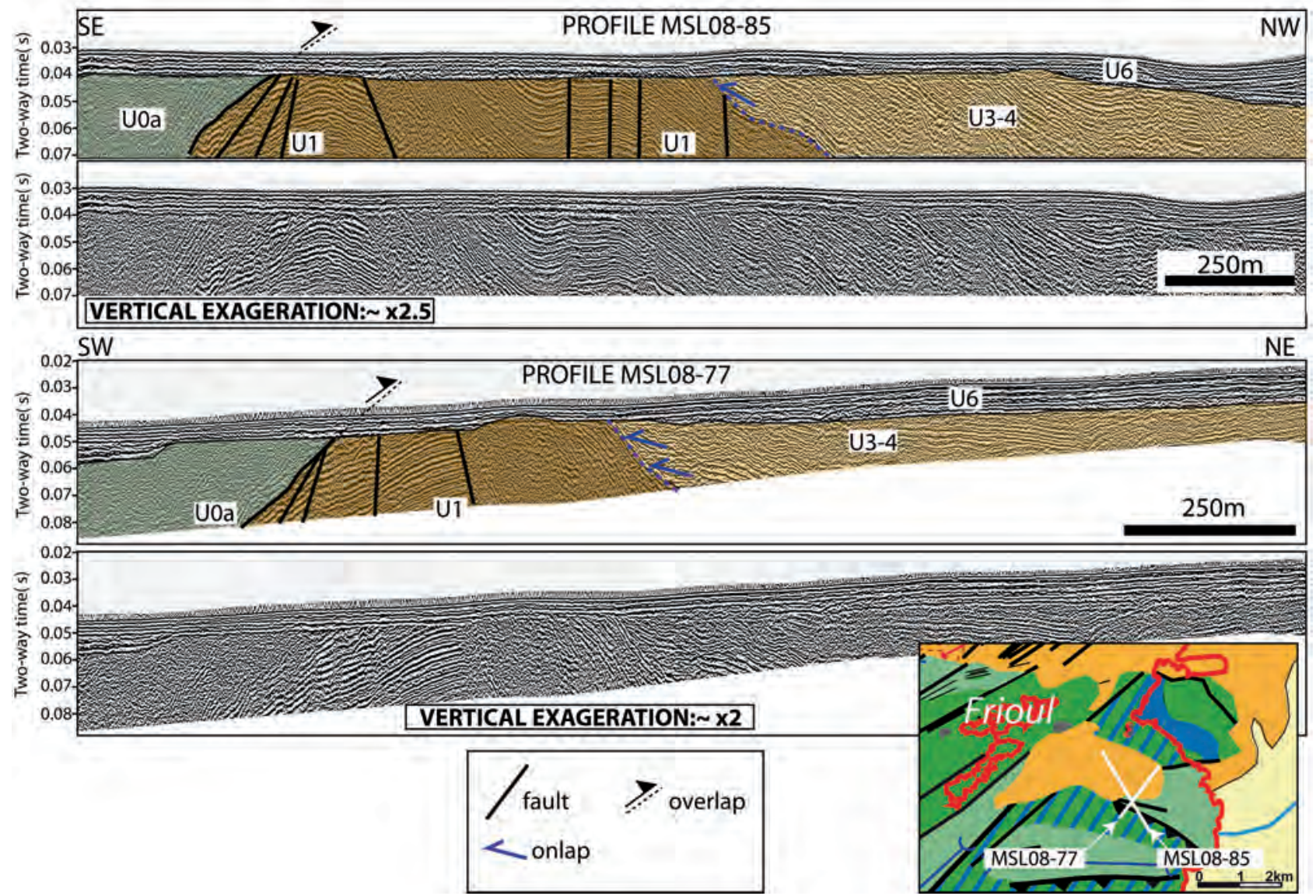

FIG. 5. - VHR sparker seismic images and interpretation of profiles A) MSL08-77 and B) MSL08-85, both located south of Frioul (see location in fig. 1 and 21). U0a: Lower Cretaceous (Berriasian to Hauterivian); U1: Aptian-Albian; U3-4: syn-rift to early post-rift (Rupelian to early Burdigalian); U6: Plio-Quaternary.

( samples a1, a2, a3, a4, a5 and a6: table III) are black marls and glauconitic, siliceous sponge-rich limestones that exhibit similar facies to that of Aptian and Albian outcrops from the Toulon area [Froget, 1971], 2) the stratified seismic pattern suggests sharp and high-frequency vertical variations in lithology that are consistent with limestone-marl alternations, and 3) unit U1 is in apparent stratigraphic conformity with the top of unit U0 (Urgonian limestones). The vertical change in seismic facies from chaotic to layered may represent an upward transition from the massive Urgonian limestones to well-stratified Bedoulian limestones and argillaceous limestones. The base of the unit U1 therefore represents the drowning-event of the Urgonian platform. Onshore, in Cassis area, the thickness of the Bedoulian-Gargasian interval is around $150 \mathrm{~m}$. Offshore, south of the Riou island, the estimated thickness of U1 unit is 1100 to $1600 \mathrm{~m}$ (fig. 11) by taking an interval velocities ranging, respectively, from 3500 to $5000 \mathrm{~m} / \mathrm{s}$. In the bay of Marseille, south of the Nerthe massif, the two-way time thickness of the U1 unit may reach $0.8 \mathrm{~s}$ (fig. 9) which corresponds to a thickness ranging from $1400 \mathrm{~m}$ to $2000 \mathrm{~m}$ (with interval velocities ranging respectively from 3500 to $5000 \mathrm{~m} / \mathrm{s}$ ).

\section{Unit U2 (Upper Cretaceous)}

The unit U2 unconformably overlies unit U1 (AptianAlbian). Unit 2 was recognized between Cassis and Saint-
Cyr-sur-Mer, South of Soubeyrane cliffs (fig. 7), in the bay of La Ciotat (fig. 3), south of the Riou island (fig. 11), and in the bay of Marseille, south of the Nerthe massif (fig. 9). U2 unit reflectors exhibits onlap and/or downlap terminations over U1 unit, south of the Riou island (fig. 11) and in the bay of Marseille (fig. 9). In high-resolution sparker profiles, this unit display in its lower part a well stratified seismic facies, with high-frequency, low to medium amplitude reflectors (fig. 7). South of La Ciotat, the top of this unit is characterized, on air-gun profiles, by deformed, low continuity reflectors (fig. 3). By comparison with the formations identified onshore, unit U2 is assigned to the Upper Cretaceous (Cenomanian to Santonian) on the basis of the following arguments: 1) a sea-bottom core sample (CR57b: table II) extracted in the bay of Cassis at the base of the unit yielded the Hedbergella - Rotalipora foraminiferal assemblage that indicates a Cenomanian age [Tassy, 2012], 2) the unconformable contact between $\mathrm{U} 1$ and $\mathrm{U} 2$ is comparable to the angular unconformity between Aptian (Gargasian) marls and Cenomanian quartzose limestones observed onshore in Cassis (fig. 7), and 3) the well-stratified seismic pattern in the lower part of unit 2 is consistent with alternating argillaceous limestone-marl alternations (Cenomanian to Lower Turonian). The seismic facies change, from stratified to chaotic, at top of Unit 2 is in agreement with the transition from basinal limestone-marl alternations of the Cenomanian-Lower Turonian [Jolet, 1996] to complex sedimentary architectures of the mid-Turonian to Coniacian 


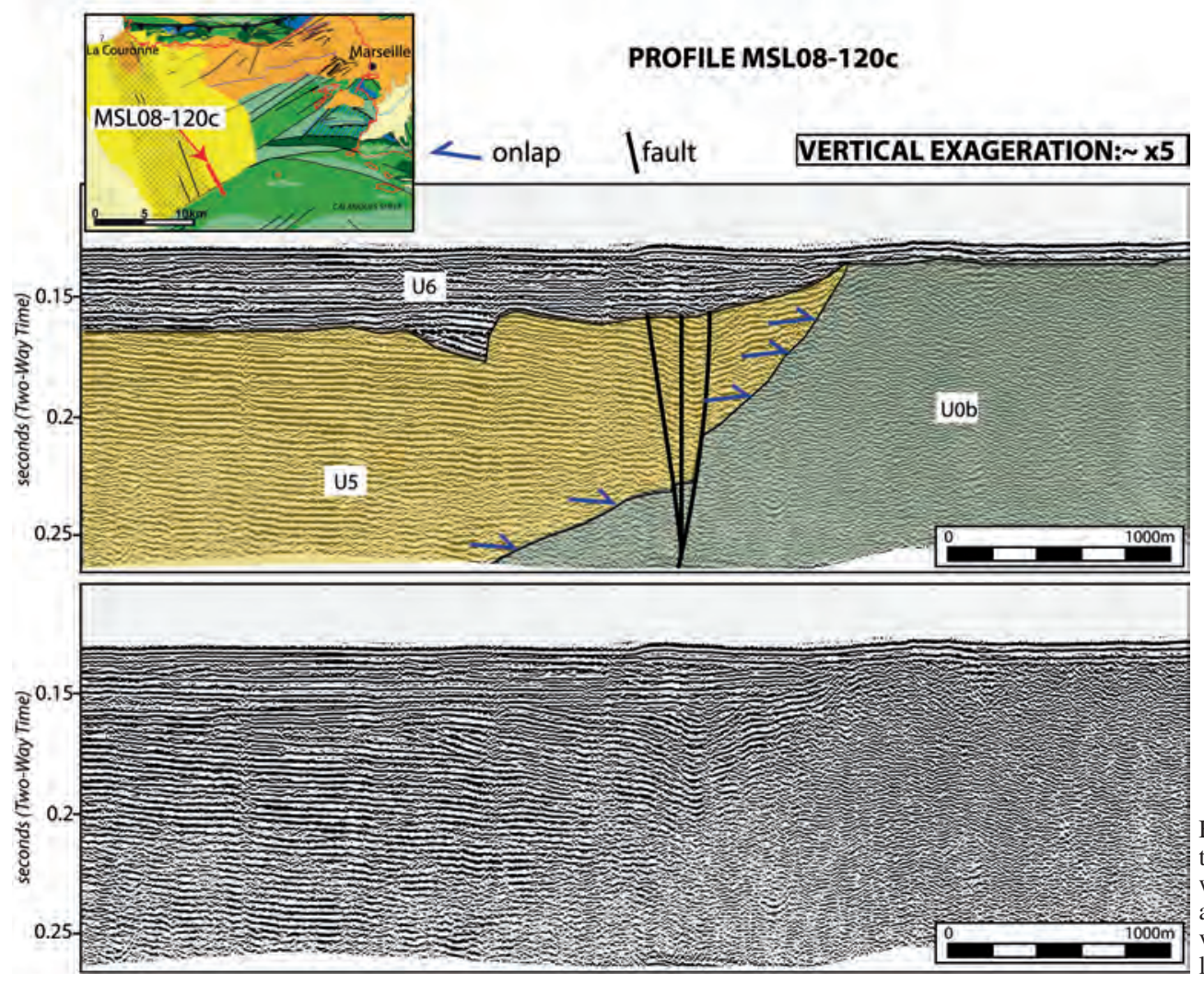

FIG. 6. - VHR sparker seismic image and inerpretation of profile MSL08-120c, located west of Planier Island (see location in fig. 1 and 21). U0b: Lower Cretaceous (Hauterivian-Barremian); U5: post-rift (mid-Burdiga lian to Messinian); U6: Plio-Quaternary.
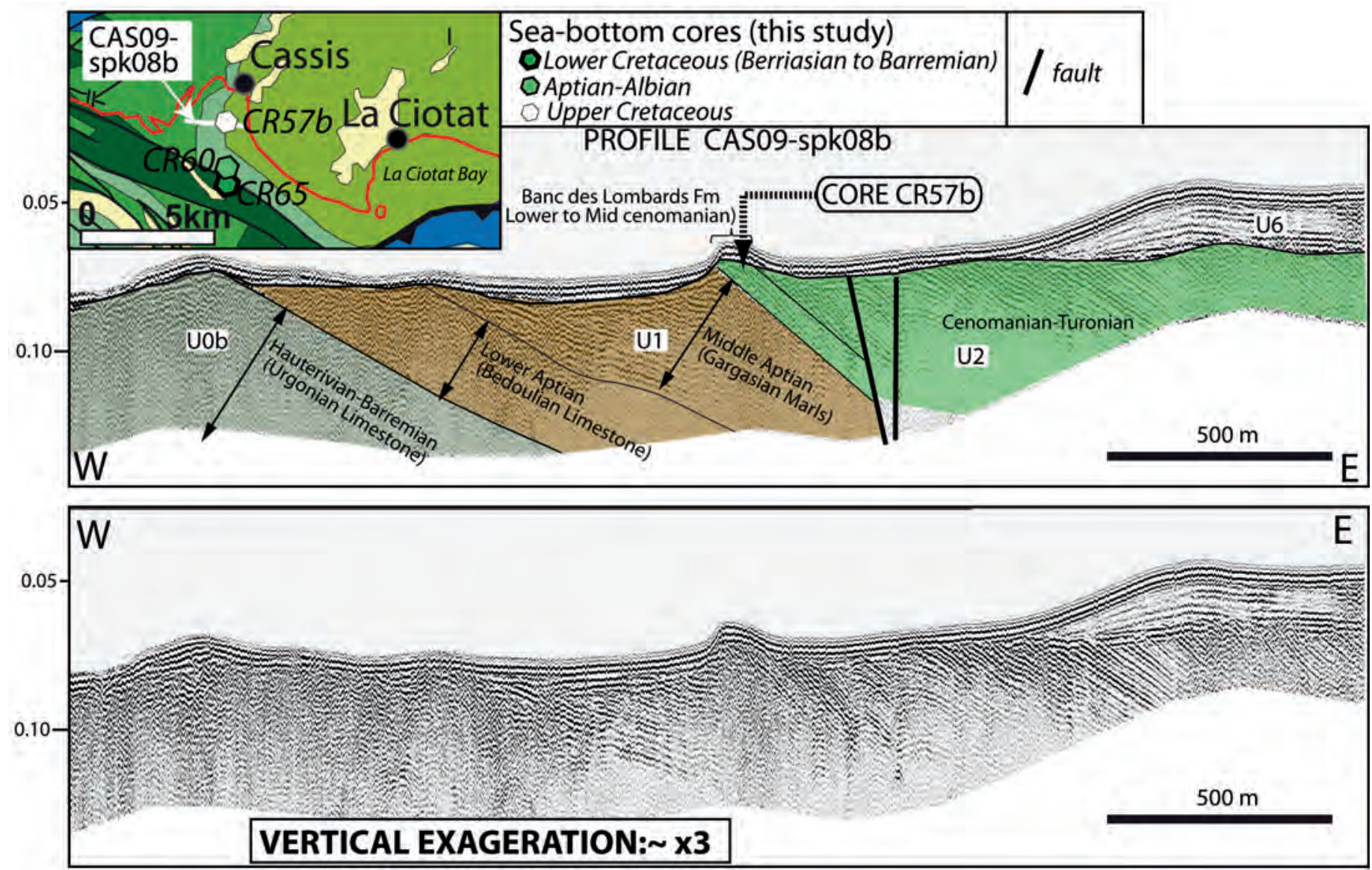

FIG. 7. - VHR sparker seismic image and interpretation of profile CAS09-spk08b, located in the bay of Cassis (see location in fig. 1). U0b: Lower Cretaceous (Hauterivian-Barremian); U1: Aptian-Albian; U2: Upper Cretaceous; U6: Plio-Quaternary. 
interval consisting of basinal quartzose calcarenites interbedded with redeposited carbonate bodies (olistolites, breccia and calciturbidites) and Gilbert-delta bottomset conglomerates [Floquet and Hennuy 2003].

Onshore, the total thickness of the Upper Cretaceous marine deposits of the Beausset syncline (Cassis-La Ciotat area) averages $1600 \mathrm{~m}$ [Fournillon, 2013]. Offshore, the maximal two-way time thickness of the assumed Upper Cretaceous deposits (unit U2) is $0.6 \mathrm{~s}(\sim 1000$ to $1500 \mathrm{~m}$ with interval velocities ranging respectively from 3500 to $5000 \mathrm{~m} / \mathrm{s}$ ), in the bay of Marseille, (fig. 9), whereas in the Riou syncline it is higher than $0.1 \mathrm{~s}(\sim 175-250 \mathrm{~m})$.

\section{Unit U3 (Rupelian-Chattian)}

The U3 unit is identified in the bay of Marseille and is characterized by a stratified seismic facies with medium-low frequency, high amplitude, folded reflectors both on sparker
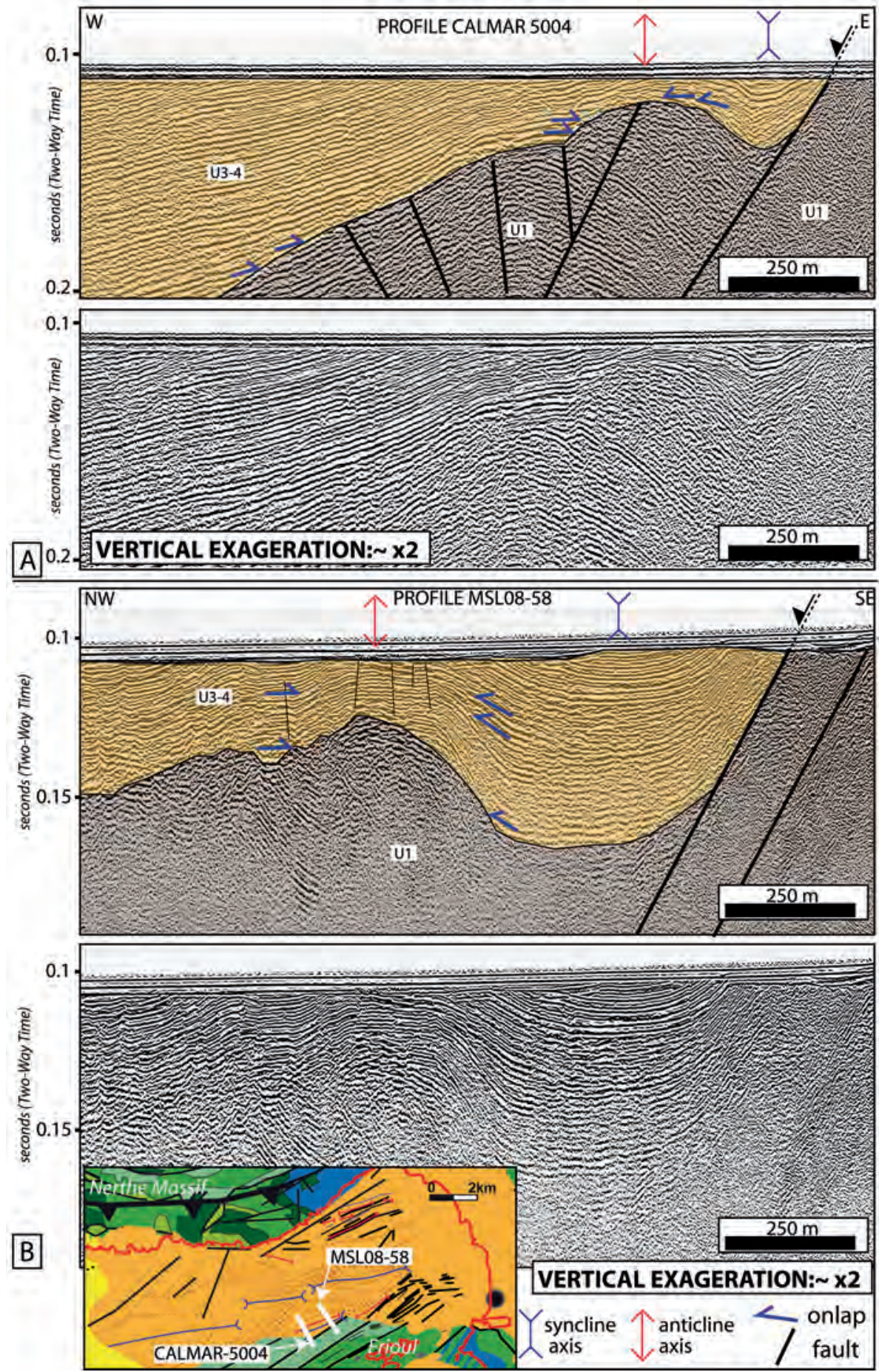

FIG. 8. - VHR seismic images and interpretation of profiles A) CALMAR-5004 and B) MSL08-58, both located north of Frioul islands, on the southern margin of the Oligo-Miocene Marseille extensional basin (see location in fig. 1 and 21). U1: Aptian-Albian; U3-4: syn-rift to early post-rift (Rupelian to early Burdigalian). 


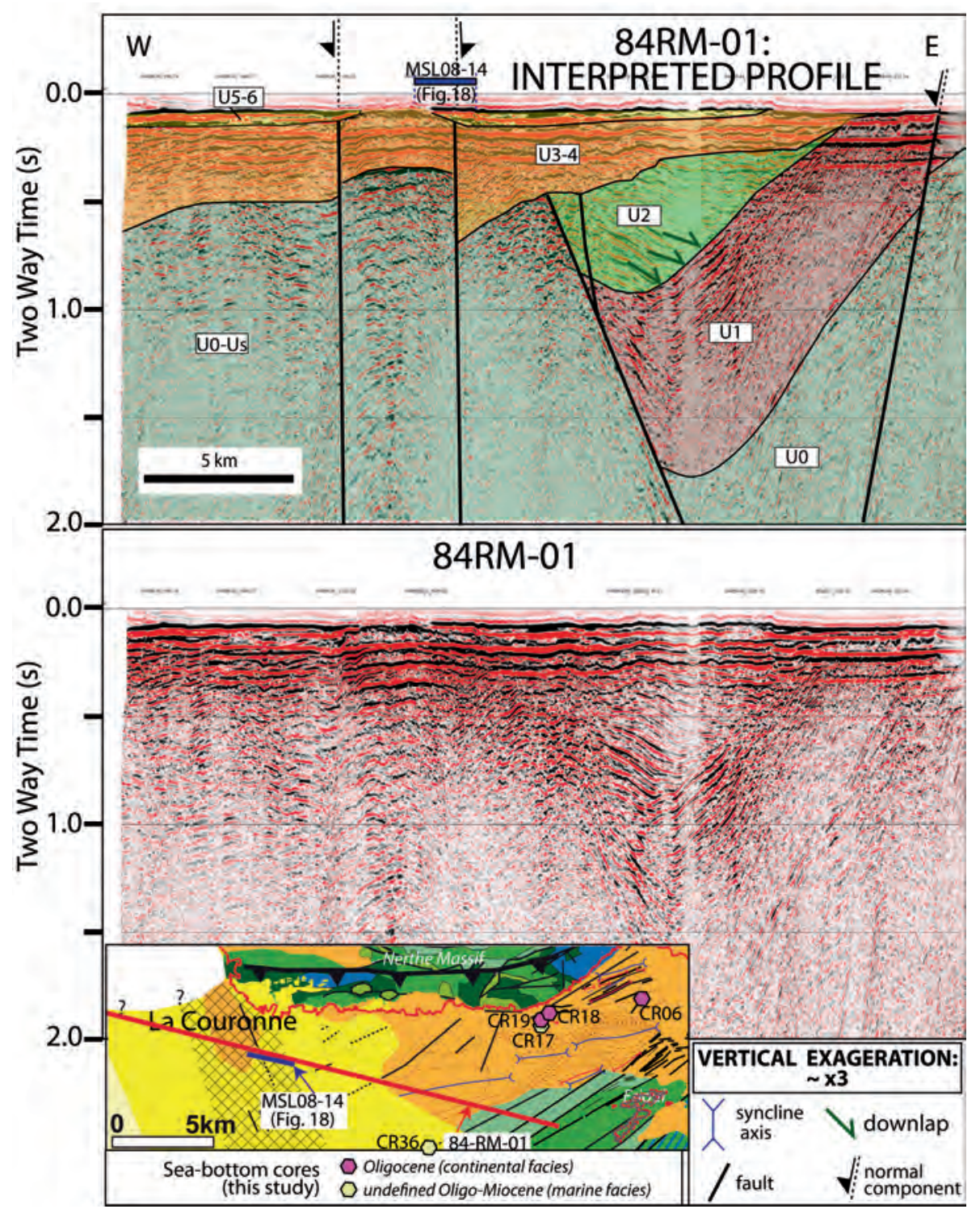

FIG. 9. - Oil-industry air-gun seismic image and interpretation of profile 84RM-01, located in the bay of Marseille (see location in fig. 1 and 21). Us: acoustic basement (pre-Cretaceous), U0: Lower Cretaceous (Berriasian to Barremian); U1: Aptian-Albian; U2: Upper Cretaceous; U3-4: syn-rift to early post-rift (Rupelian to early Burdigalian); U5-6: undifferenciated post-rift Miocene (mid-Burdigalian to Messinian) and Plio-Quaternary.

and air-gun profiles (fig. 12). This unit has been identified mainly north of the bay of Marseille where it is unconformably overlain by the U4 unit. U3 unit is in most cases difficult to distinguish from the overlying U4 unit. As a consequence, units U3 and U4 have been grouped as one single unit in the geological map of the offshore continental shelf (fig. 2). Unit 3 is interpreted to represent Lower Oligocene (Rupelian) continental deposits, based on the following criteria: 1) two cored samples (CR18 and CR19: table II) from this unit are pedogenetized (palustrine?) limestones with ostracods and freshwater gastropods that are similar in depositional facies to Rupelian continental carbonates from the Marseille basin [Nury, 1988; Tassy, 2012], 2) unit 3 occurs in structural continuity with the Rupelian continental deposits from L'Estaque area, in the Marseille Oligocene basin, and 3) well stratified seismic facies is consistent with sharp and rapid vertical variations in lithology (limestone, clays and sandstones).

\section{Unit U4 (Chattian-Lower Burdigalian)}

The unit 4 (U4) is made of a set of parallel, continuous, high-frequency, folded reflectors. In the bay of Marseille, this unit is conformable or slightly unconformable on unit 3 (fig. 12 and 13). Unit 4 is not distinguished from unit 3 in the southern bay of Marseille and south of the Frioul islands. Units 3 and 4 are affected by post-depositional tectonic deformation characterized by $\mathrm{E}-\mathrm{W}$ trending folds. Unit 4 has been attributed to Chattian to lower Burdigalian syn-rift to early post-rift deposits [Oudet et al., 2010] on the basis of the structural continuity with the onshore outcrops (fig. 14, 15 and 16). The top of unit 4 is correlatable onshore with the top of the "biodetrital Sausset-les-Pins unit" (SB2 unconformity sensu Oudet et al. [2010]) that was interpreted to represent the top of the early post-rift "Lower Transgressive Group" of Gorini et al. [1993]. In the upper part of unit 4, south of La Nerthe massif, between 


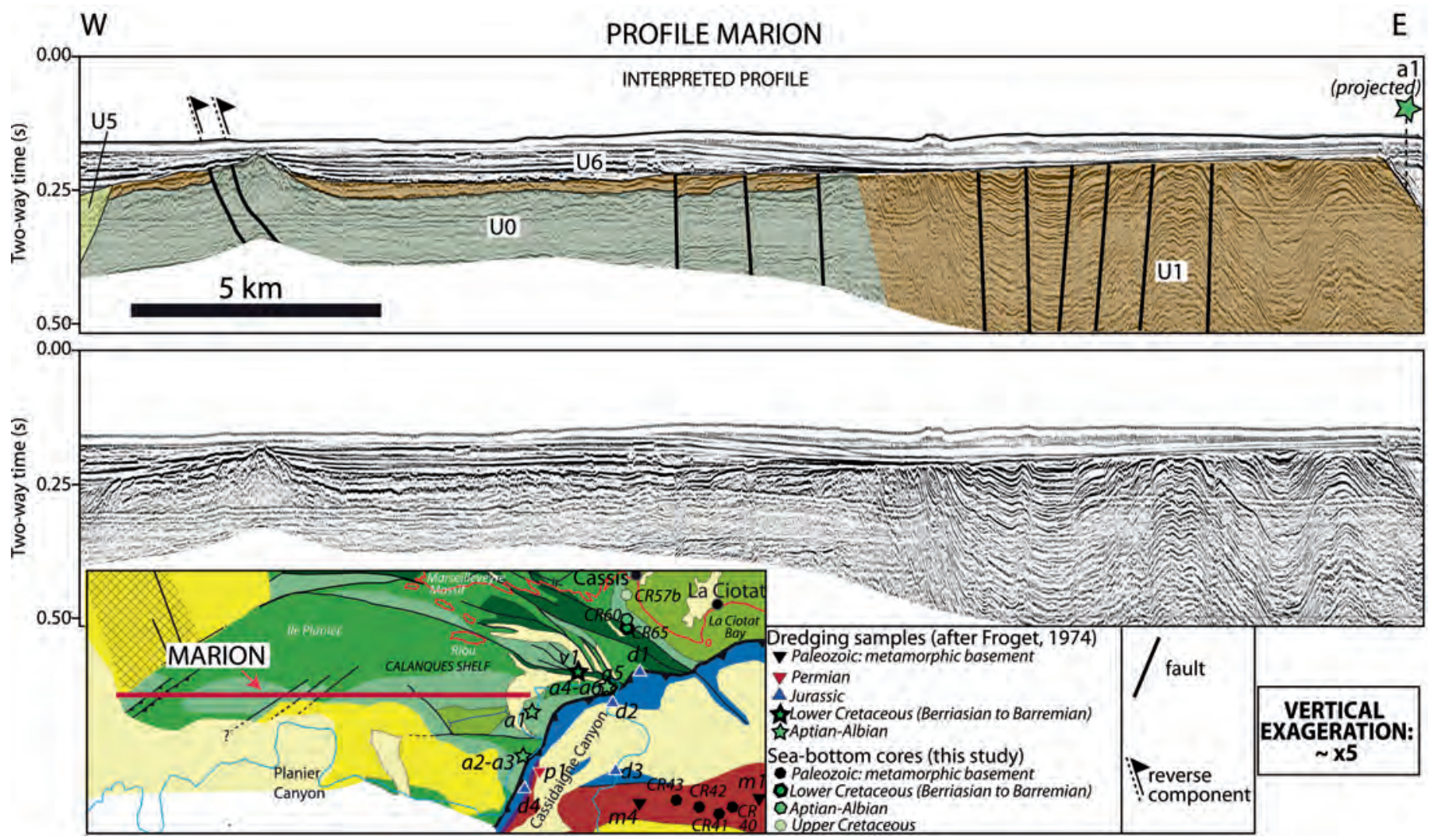

FIG. 10. - Seismic image and interpretation of profile MARION, across the Calanques shelf (see location in fig. 1). U0: Lower Cretaceous (Berriasian to Barremian); U1: Aptian-Albian; U5: post-rift (mid-Burdigalian to Messinian); U6: Plio-Quaternary.

TABLE III - Seabed rock samples from dredging surveys [after Froget, 1974]

\begin{tabular}{|c|c|c|c|c|c|}
\hline Sample name & $\mathbf{x}$ & $\mathbf{Y}$ & $\begin{array}{c}\text { Water } \\
\text { depth } \\
\text { (m) }\end{array}$ & Sample description & Age \\
\hline C3 & $43^{\circ} 08.160$ & $05^{\circ} 25.490$ & 90 & & Würm IV-Holocene \\
\hline C4 & $43^{\circ} 04.285$ & $05^{\circ} 21.760$ & 190 & & Würm IIIIV \\
\hline $\begin{array}{c}\text { R48-R84-R88- } \\
\text { R139-R180 }\end{array}$ & $43^{\circ} 08.150$ & $05^{\circ} 27.600$ & $250-500$ & argilaceous carbonate sands & Pliocene \\
\hline R86 & $43^{\circ} 08.150$ & $05^{\circ} 27.600$ & $150-200$ & red algal calcarenite and calcirudite & Pliocene \\
\hline R109-R110 & $43^{\circ} 06.580$ & $05^{\circ} 32.720$ & $150-201$ & red algal calcarenite and calcirudite & Pliocene \\
\hline R15 & $43^{\circ} 01.180$ & $05^{\circ} 30.900$ & 270 & Halimeda limestone & Upper Miocene? \\
\hline R16 & $43^{\circ} 01.180$ & $05^{\circ} 30.900$ & 250 & Halimeda limestone & Upper Miocene? \\
\hline R165 & $43^{\circ} 06.315$ & $05^{\circ} 15.450$ & 275 & foraminiferal-molluskal calcarenite & Pleistocene \\
\hline R171 & $43^{\circ} 06.840$ & $05^{\circ} 15.450$ & 200 & foraminiferal-molluskal calcarenite & Pleistocene \\
\hline R181 & $43^{\circ} 06.840$ & $05^{\circ} 13.450$ & & conglomerate & Pleistocene \\
\hline R17 & $43^{\circ} 03.03$ & $05^{\circ} 24.360$ & 170 & red algal calcarenite & Pleistocene \\
\hline R18 & $43^{\circ} 03.03$ & $05^{\circ} 24.360$ & 190 & red algal calcarenite & Pleistocene \\
\hline $\mathbf{R 2 0}$ & $43^{\circ} 04.255$ & $05^{\circ} 30.220$ & $30-340$ & red algal calcarenite and calcirudite & Pliocene \\
\hline $\mathbf{R 5 1}$ & $43^{\circ} 03.03$ & $05^{\circ} 24.360$ & $180-200$ & red algal calcarenite & Pleistocene \\
\hline R47 & $43^{\circ} 05.920$ & $05^{\circ} 27.270$ & 200 & molluskal-algal calcarenite & Pleistocene \\
\hline a1 & $43^{\circ} 07.100$ & $05^{\circ} 26.200$ & 150 & marls and glauconitic limestones & Aptian \\
\hline a2 & $43^{\circ} 05.400$ & $05^{\circ} 25.800$ & & marls and glauconitic limestones & Aptian \\
\hline a3 & $43^{\circ} 05.300$ & $05^{\circ} 26.100$ & & marls and glauconitic limestones & Aptian \\
\hline a4 & $43^{\circ} 08.150$ & $05^{\circ} 31.400$ & 150 & siliceous limestone with Sponge spicula & Aptian \\
\hline a5 & $43^{\circ} 08.300$ & $05^{\circ} 31.000$ & 220 & marls & Aptian \\
\hline a6 & $43^{\circ} 08.000$ & $05^{\circ} 31.000$ & 200 & marls & Aptian \\
\hline v1 & $43^{\circ} 08.600$ & $05^{\circ} 29.500$ & 180 & limestone & Valanginian \\
\hline d1 & $43^{\circ} 08.74$ & $05^{\circ} 32.78$ & 5 & dolostone & Upper Jurassic? \\
\hline d2 & $43^{\circ} 07.08$ & $05^{\circ} 31.150$ & 160 & dolostone & Upper Jurassic? \\
\hline d3 & $43^{\circ} 05.150$ & $05^{\circ} 31.000$ & $150-300$ & dolostone & Upper Jurassic? \\
\hline d4 & $43^{\circ} 04.150$ & $05^{\circ} 25.300$ & 200 & dolostone & Upper Jurassic? \\
\hline $\mathrm{m} \mathbf{1}$ & $43^{\circ} 04.300$ & $05^{\circ} 39.850$ & 110 & phyllade & Paleozoic \\
\hline m2 & $43^{\circ} 02.000$ & $05^{\circ} 42.850$ & $150-200$ & phyllade & Paleozoic \\
\hline m3 & $43^{\circ} 01.600$ & $05^{\circ} 44.300$ & $150-200$ & phyllade & Paleozoic \\
\hline $\mathrm{m} 4$ & $43^{\circ} 03.600$ & $05^{\circ} 33.150$ & & phyllade & Paleozoic \\
\hline m5 & $43^{\circ} 04.150$ & $05^{\circ} 30.000$ & $150-350$ & conglomerate with metamorphic pebbles & Pliocene \\
\hline p1 & $43^{\circ} 05.250$ & $05^{\circ} 27.000$ & 200 & Sandstone (quartzarenite) with siliceous cement & Permian \\
\hline
\end{tabular}



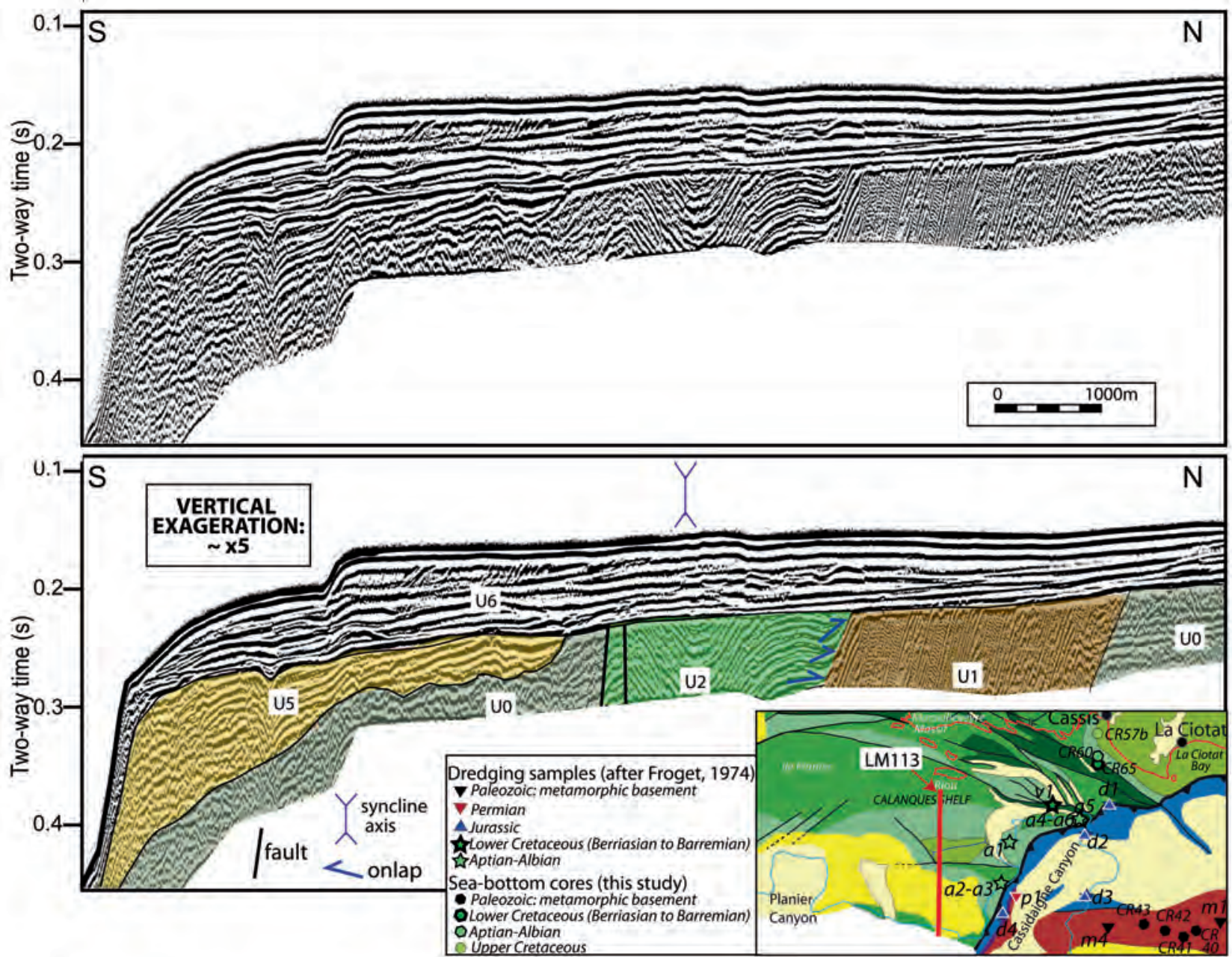

FIG. 11. - HR air-gun seismic image and interpretation of profile LM113, located in the Calanques shelf, south of Riou island (see location in fig. 1). U0: Lower Cretaceous (Berriasian to Barremian); U1: Aptian-Albian; U2: Upper Cretaceous; U5: post-rift (mid-Burdigalian to Messinian); U6: Plio-Quaternary.

Carry-Le-Rouet and La Couronne, seismic profiles (fig. 15) exhibit a significant unconformity (enveloppe of toplaps terminations) that is overlain by a set of onlapping reflectors. Such an unconformity may represent the SB1 unconformity or "break-up unconformity" of Oudet et al. [2010]. A sample of benthic foraminiferal-scleractinian packstone (CR17: table II) was collected in this unit south of the Nerthe massif, that displays similar features to Chattian-Aquitanian shallow-water limestones studied onshore [Tassy, 2012]. In the onshore Marseille basin, the thickness of Oligocene deposits is higher than $800 \mathrm{~m}$ [Nury, 1988]. Offshore, the maximal two-way time thickness of the unit U4 is approximately $0.6 \mathrm{~s}$. The average value of 44 brine-saturated $\mathrm{P}$-wave velocities calculated by using Gassmann relationship from laboratory measurements of Oligo-Miocene dry outcrop samples of various lithologies and facies [Oudet, 2008] is around $3200 \mathrm{~m} / \mathrm{s}$. If one considers this value as a correct estimate of average interval velocity of Oligo-Miocene deposits, the maximum thickness of U3 and U4 units would average $960 \mathrm{~m}$ in the bay of Marseille.

\section{Unit U5 (Mid Burdigalian to Messinian)}

Unit 5 (U5) is characterized by a stratified, high frequency and high amplitude seismic facies. South of La Nerthe massif, this unit unconformably overlies unit U4 (fig. 17 and 18) and consists of a set of undeformed reflectors that are gently dipping to the SW (fig. 15, 16 and 17). South of Cap Couronne, unit U5 is affected by subvertical faults and short-wavelength folds of undefined orientation along a N160-trending deformation belt (fig. 17, 19 and 20). Along this deformed belt, seismic facies within Unit U5 may become almost transparent or with discontinuous, low amplitude reflectors. South of the Marseille bay, unit U5 is affected by reverse faults, at the vicinity of the contact with the Mesozoic basement (U0 unit) from the seaward prolongation of the Marseilleveyre massif (fig. 6). In the Calanques and Blauquières area, at the margin of the continental shelf, unit U5 forms a sedimentary wedge, prograding southwards, that onlaps the Mesozoic (fig. 11) or the Paleozoic basement. This unit is bounded at top by the Messinian erosional surface. The lower part of unit U5 


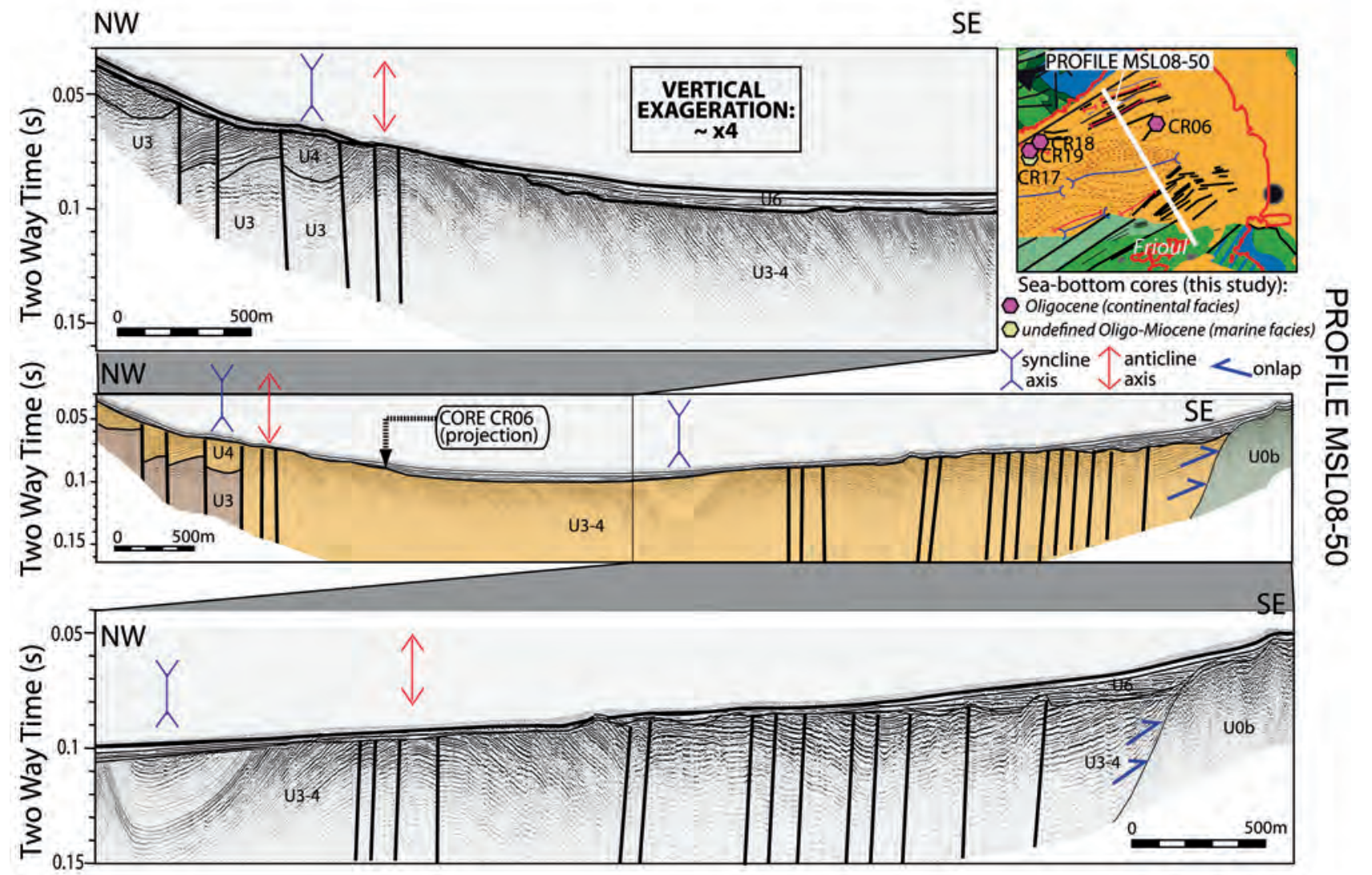

FIG. 12. - VHR sparker seismic image and interpretation of profile MSL08-50, located in the bay of Marseille (see location in fig. 1 and 21). U0b: Lower Cretaceous (Hauterivian-Barremian); U3: syn-rift (Rupelian); U4: syn-rift to early post-rift (Chattian to early Burdigalian); U6: Plio-Quaternary.

correlates onshore with the mid to upper Burdigalian "Plan de Sausset unit" and "La Couronne Limestone unit" (fig. 14 and 15). This unit can be attributed to post-rift ("Upper Prograding Group" sensu Gorini et al. [1993]) and preMessinian formations [Oudet et al., 2010]. Halimeda-rich limestones (samples R15-R16: table III) were collected from this unit [Froget, 1974] south of the Blauquières bank. The maximum two-way time thickness of unit U5 is $0.2 \mathrm{~s}$ which would represent a thickness of approximately $320 \mathrm{~m}$ by considering a $3200 \mathrm{~m} / \mathrm{s}$ interval velocity.

\section{Unit U6 (Plio-Quaternary)}

Unit U6 is composed of a set of parallel, subhorizontal to oblique, sometimes sigmoidal, continuous reflectors, on both sparker and air-gun profiles (e.g. fig. 4 and 17). On the Blauquières bank, this unit exhibits in its lower part a well-stratified seismic facies, with low-frequency and high amplitude reflectors. In this area, unit U6 represents the sedimentary infill of Messinian canyons [Tassy, 2012; Tassy et al., 2014]. All samples collected from this unit provided Pliocene to Pleistocene ages [Froget, 1974; Tassy, 2012; tables II and III]. Onshore, the Bandol conglomerates, assigned to the Pliocene by Coulon [1967] could represent a lateral equivalent of the offshore unit U6.

\section{Tectonostratigraphic framework of the Provence continental shelf}

The offshore Provence continental shelf can be subdivided into three main structural domains (fig. 2). The western area, south of the Nerthe massif (Côte Bleue and bay of Marseille), represents the seaward extension of the Marseille Oligocene basin (fig. 1). The central area, located between the Planier island and the Cassidaigne canyon, is a submarine plateau composed of highly deformed Mesozoic rocks which was significantly eroded during the MSC event and by marine abrasion during Plio-Quaternary transgressions [Froget, 1974; Collina-Girard, 1999]. The eastern area (Blauquières bank), extending from the Cassidaigne canyon to the Cap Sicié, is regarded as the seaward extension of the Bandol and Cap Sicié thrust-belts [Ducrot, 1967; Froget, 1974].

\section{The Côte Bleue and the Bay of Marseille}

The portion of the continental shelf bounded to the north by the Nerthe massif and to the south by the Frioul horst (fig. 2) is interpreted as the western extension of the Tertiary Marseille basin. The NE-SW-oriented Frioul horst is made of Mesozoic units U0 (Berriasian to Barremian) and U1 (Aptian-Albian) and is structured by a set of N050 faults with normal component. In the bay of Marseille, OligoMiocene deposits (U3 and U4) lie on a thick interval (up to 

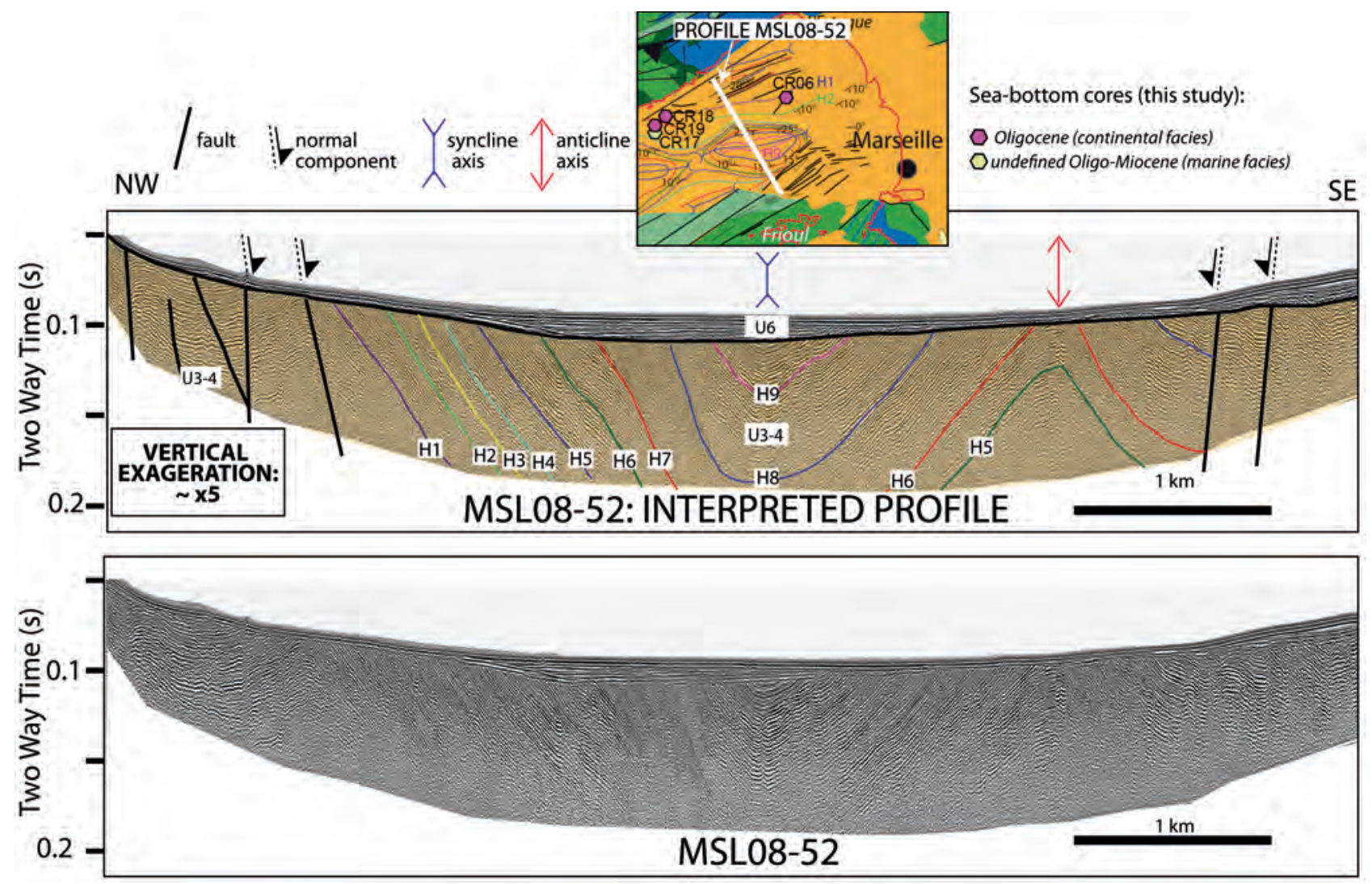

FIG. 13. - VHR sparker seismic image and interpretation of profile MSL08-52, located in the bay of Marseille (see location in fig. 1 and 21). U3-4: syn-rift to early post-rift (Rupelian to early Burdiagalian); U6: Plio-Quaternary; H1 to H9: seismic horizons.

$1.5 \mathrm{~s}$ TWT) of Aptian-Albian (U1) and Late Cretaceous (U2) basinal deposits. North of the Frioul islands, the syn-rift and early post-rift deposits (U3 and U4 units) are thick (approximately $1000 \mathrm{~m}$ ) and are structured as a set of en echelon N080-trending synclines (figs 9, 12, 13 and 21). This deformation is sealed by post-rift deposits of the U5 unit (fig. 21) whose base is assigned to the middle Burdigalian. The relatively isopachous deposition of the U4

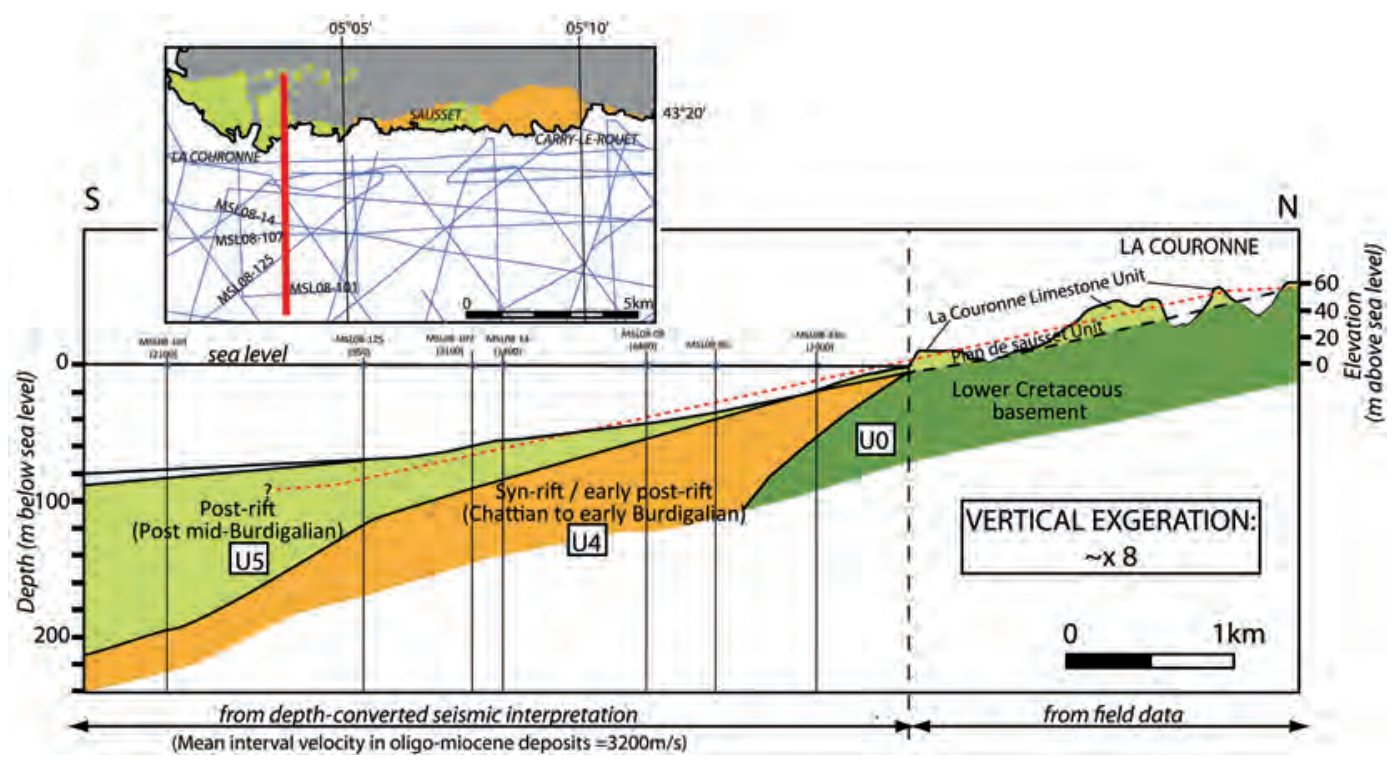

FIG. 14. - Land to sea geological cross-section based on field observations onshore and seismic interpretation offshore. Offshore, the thickness of units U4 and U5 is estimated by using a mean interval velocity of $3200 \mathrm{~m} / \mathrm{s}$. U0: Lower Cretaceous (Berriasian to Barremian); U4: syn-rift to early post-rift (Chattian to early Burdigalian); U5: post-rift (mid-Burdigalian to Messinian). Plan de Sausset and La Couronne Limestone units have been defined by Oudet $e t$ al. [2010]. 

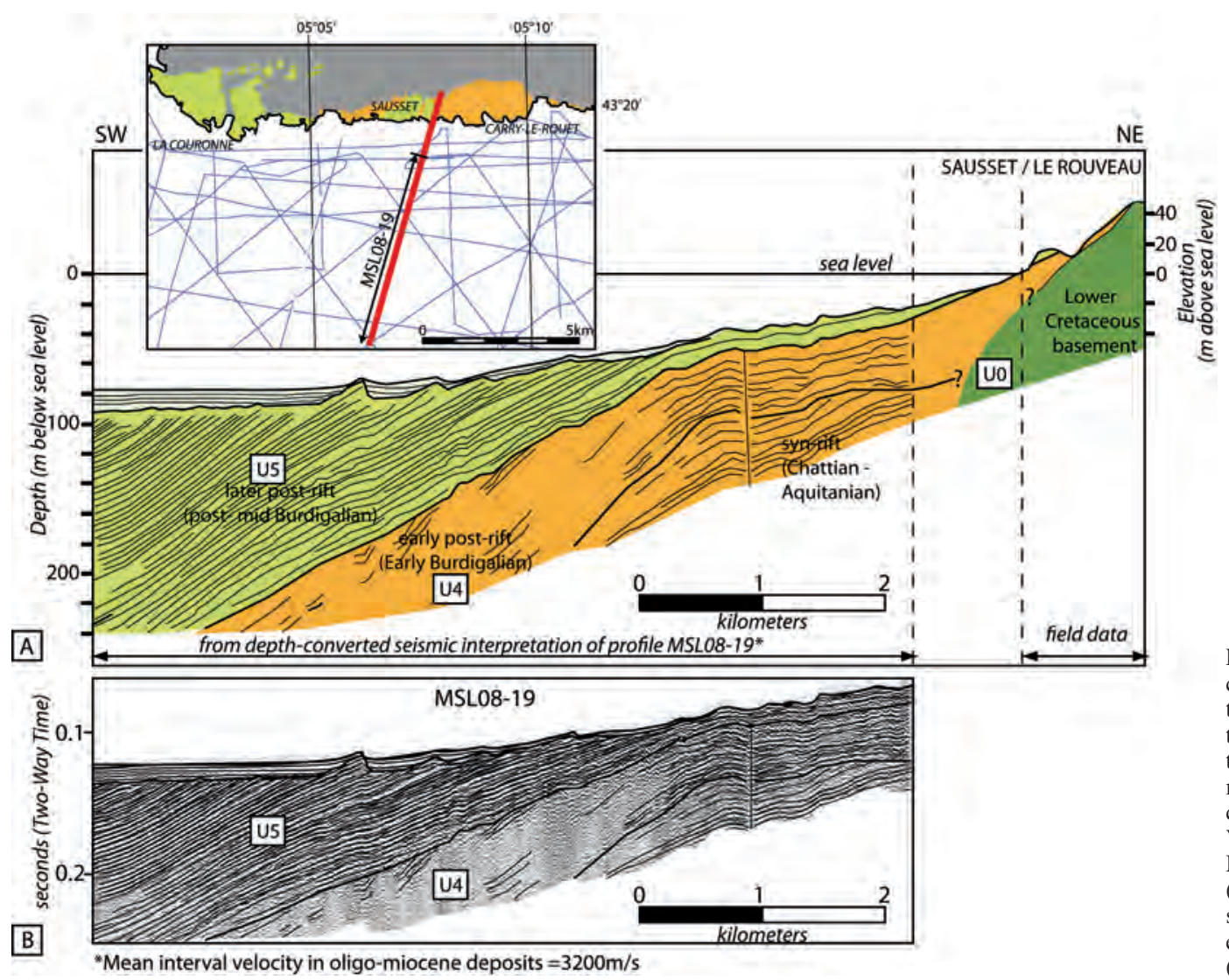

FIG. 15. - A) Land to sea geological cross-section based on field observations onshore and seismic interpretation offshore. Offshore, the thickness of units U4 and U5 is estimated by using a mean interval velocity of $3200 \mathrm{~m} / \mathrm{s}$; B) Interpretation of VHR sparker seismic profile MSL08-19. U0: Lower Cretaceous (Berriasian to Barremian); U4: syn-rift to early post-rift (Chattian to early Burdigalian); U5: post-rift (mid-Burdigalian to Messinian).
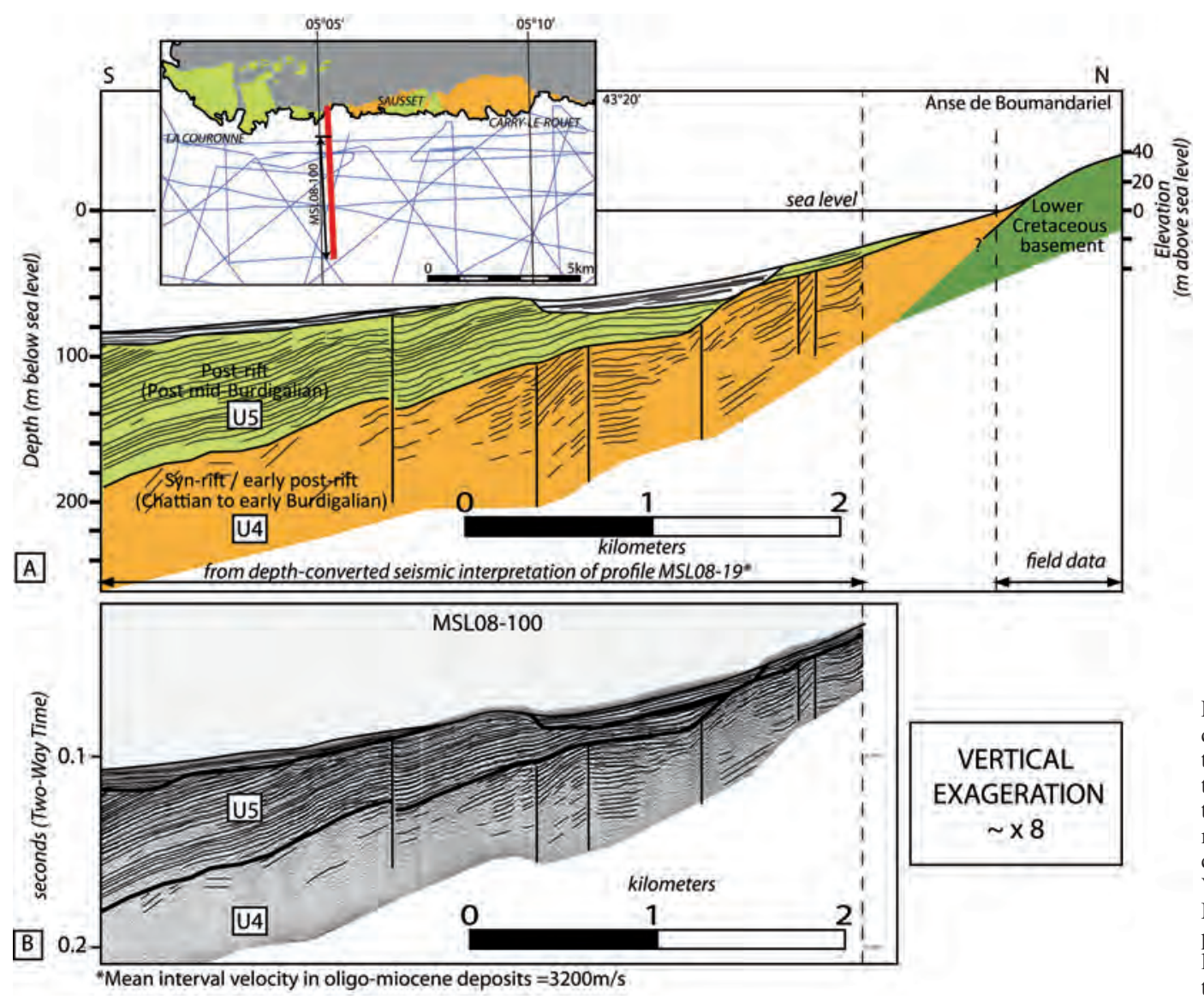

FIG. 16. - A) Land to sea geological cross-section based on field observations onshore and seismic interpretation offshore. Offshore, the thickness of units U4 and U5 is estimated by using a mean interval velocity of $3200 \mathrm{~m} / \mathrm{s} ; \mathrm{B}$ ) Interpretation of VHR sparker seismic profile MSL08-100. U4: syn-rift to early post-rift (Chattian to early Burdigalian); U5: post-rift (mid-Burdigalian to Messinian). 

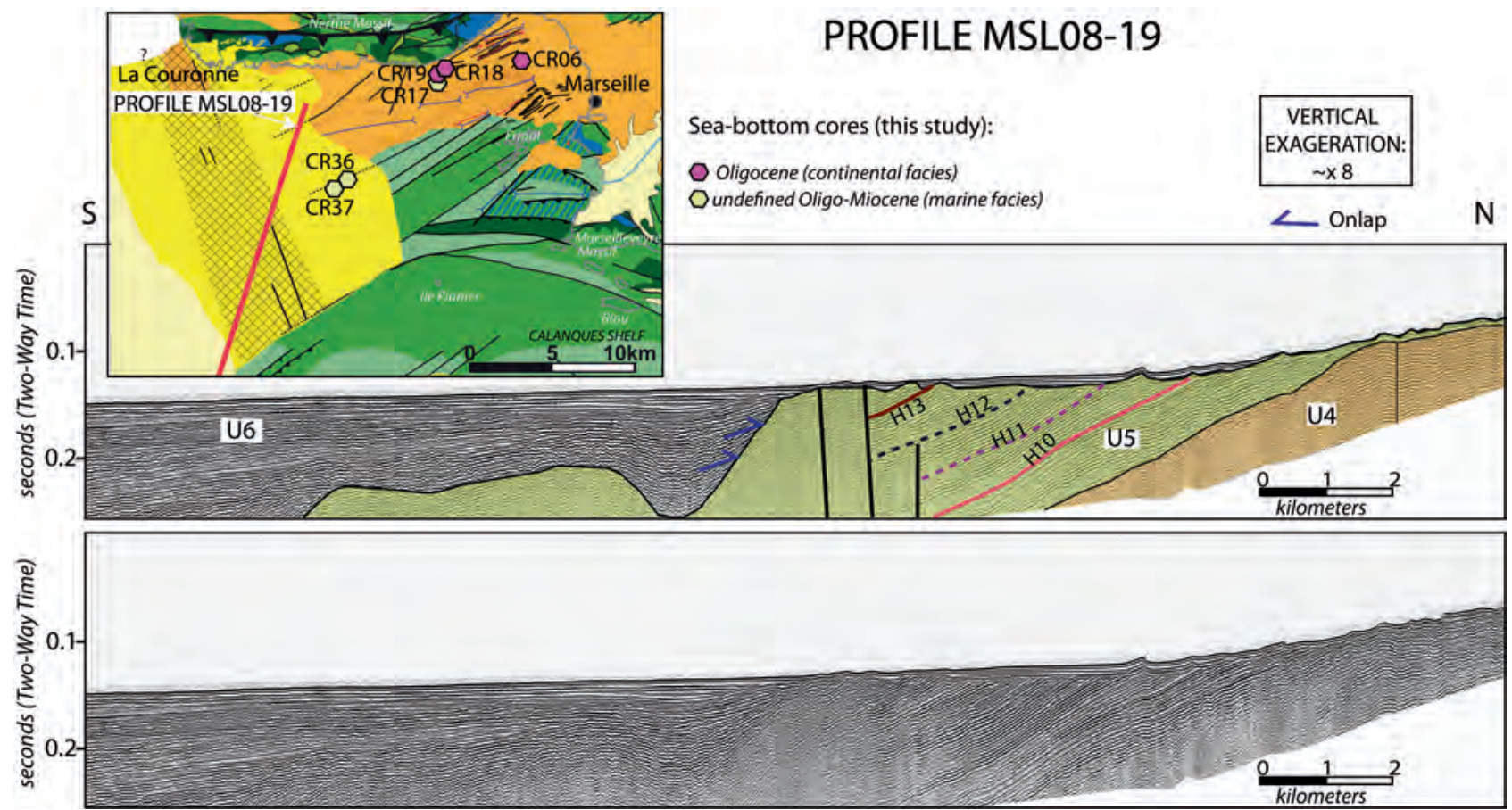

FIG. 17. - VHR sparker seismic image and interpretation of profile MSL08-19, located in the bay of Marseille (see location in fig. 1 and 21). U4: syn-rift to early post-rift (Chattian to early Burdigalian); U5: post-rift (mid-Burdigalian to Messinian); U6: Plio-Quaternary; H10 to H13: seismic horizons.

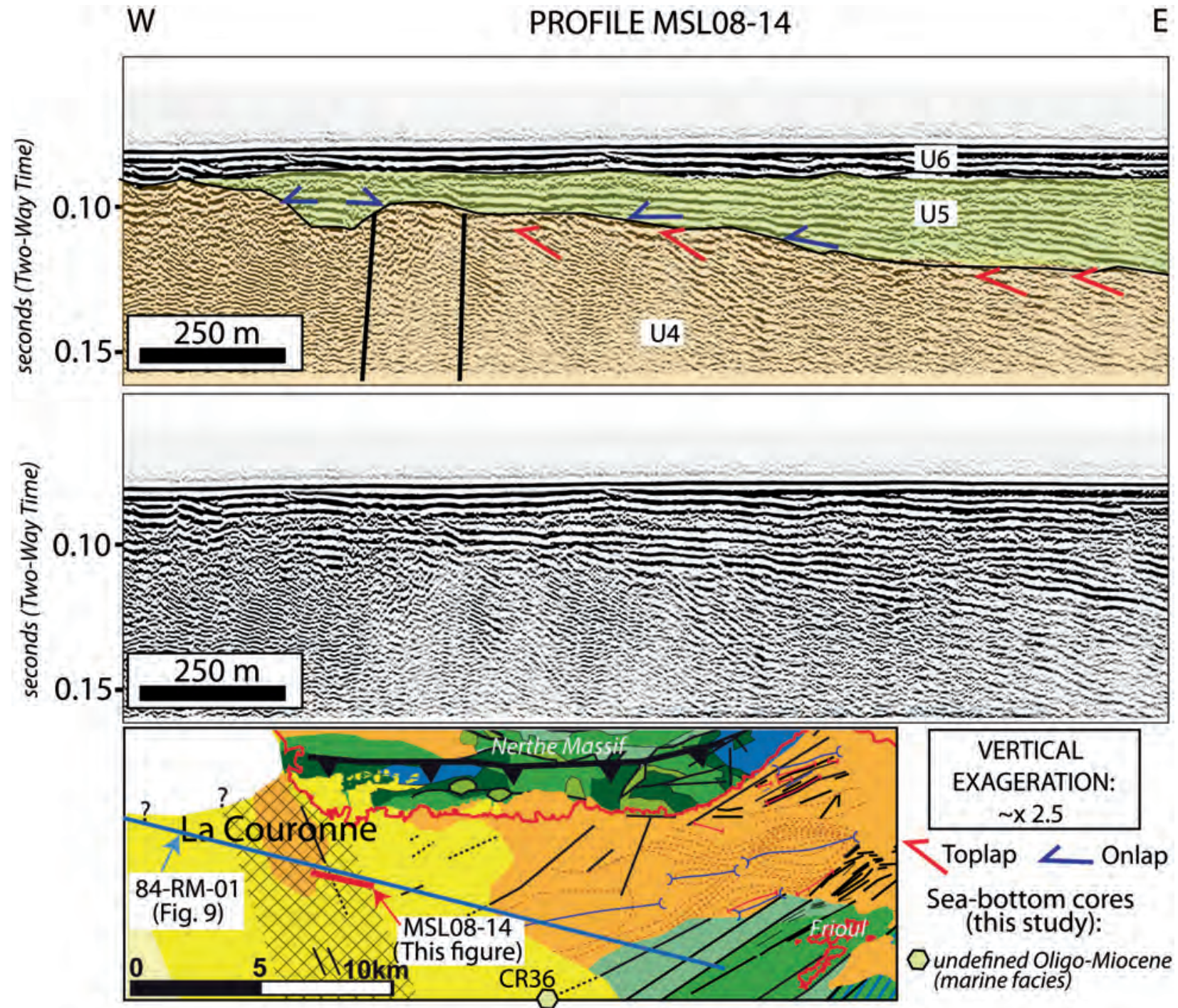



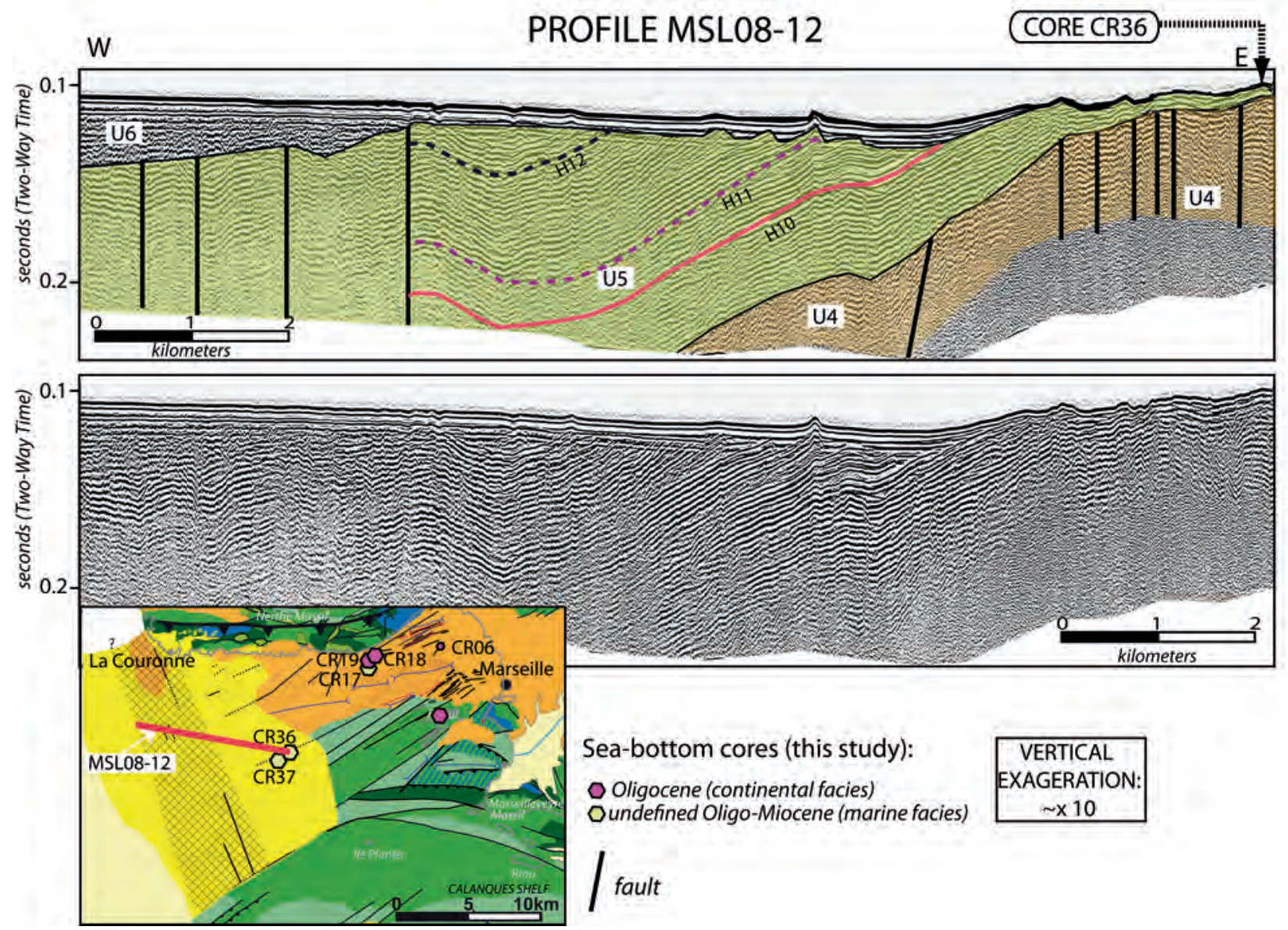

FIG. 19. - VHR sparker seismic image and interpretation of profile MSL08-12, located west of the bay of Marseille (see location in fig. 1 and 21). U4: syn-rift to early post-rift (Chattian to early Burdigalian); U5: post-rift (mid-Burdigalian to Messinian); U6: Plio-Quaternary.

unit sediments (fig. 12 and 13) in the center of the basin strongly suggests that the major phase of N080 fold development is younger than $\mathrm{U} 4$ and consequently occurred as a consequence after the early Burdigalian. The contact between U3-4 deposits and the underlying Mesozoic basement of the Frioul horst (U0 and U1 units) occurs either as passive depositional onlap (fig. 12 and 22) or as a sharp structural contact along NE-SW normal faults (fig. 8). The occurrence of drag-blocks along the NE-SW faults and associated syn-sedimentary drag-syncline and anticline development (fig. 8) indicates that the set of NE-SW faults were active during the deposition of U4 unit. East of the bay of Marseille and north of the Frioul islands, the orientation of faults affecting U3 and U4 units progressively changes eastward from NE-SW to E-W (fig. 21). Southwest of L'Estaque (NE Bay of Marseille), U3-U4 deposits are affected by N080 anticlines and synclines that are slightly oblique to dominant NE-SW faults (fig. 21). South of La
Couronne, U4 and U5 units are significantly deformed along a $5 \mathrm{~km}$-width, N160-oriented corridor (fig. 2, 18, 19 and 20). The unconformable contact of post-rift U5 unit over syn-rift to early post-rift unit U4 in this area suggests that part of the deformation occurred prior to the middle Burdigalian. South of the Frioul islands, the Oligo-Miocene series are very thin, slightly deformed and of reduced extension (fig. 5, 14 and 21). It unconformably overlies U0 and U1 units that are affected by E-W-trending thrusts and folds. West of Planier island, flower-structure-like faults affect the post-rift unit U5, suggesting a late reactivation of syn-rift N050 faults (fig. 6). In the bay of Marseille, deformed U3 and U4 units are sharply truncated below a subhorizontal surface, interpreted as a polyphased wave-cut surface that formed during the Plio-Quaternary marine transgressions. As a consequence, in the bay of Marseille, there is no evidence of preserved Messinian incision within the continental shelf. 

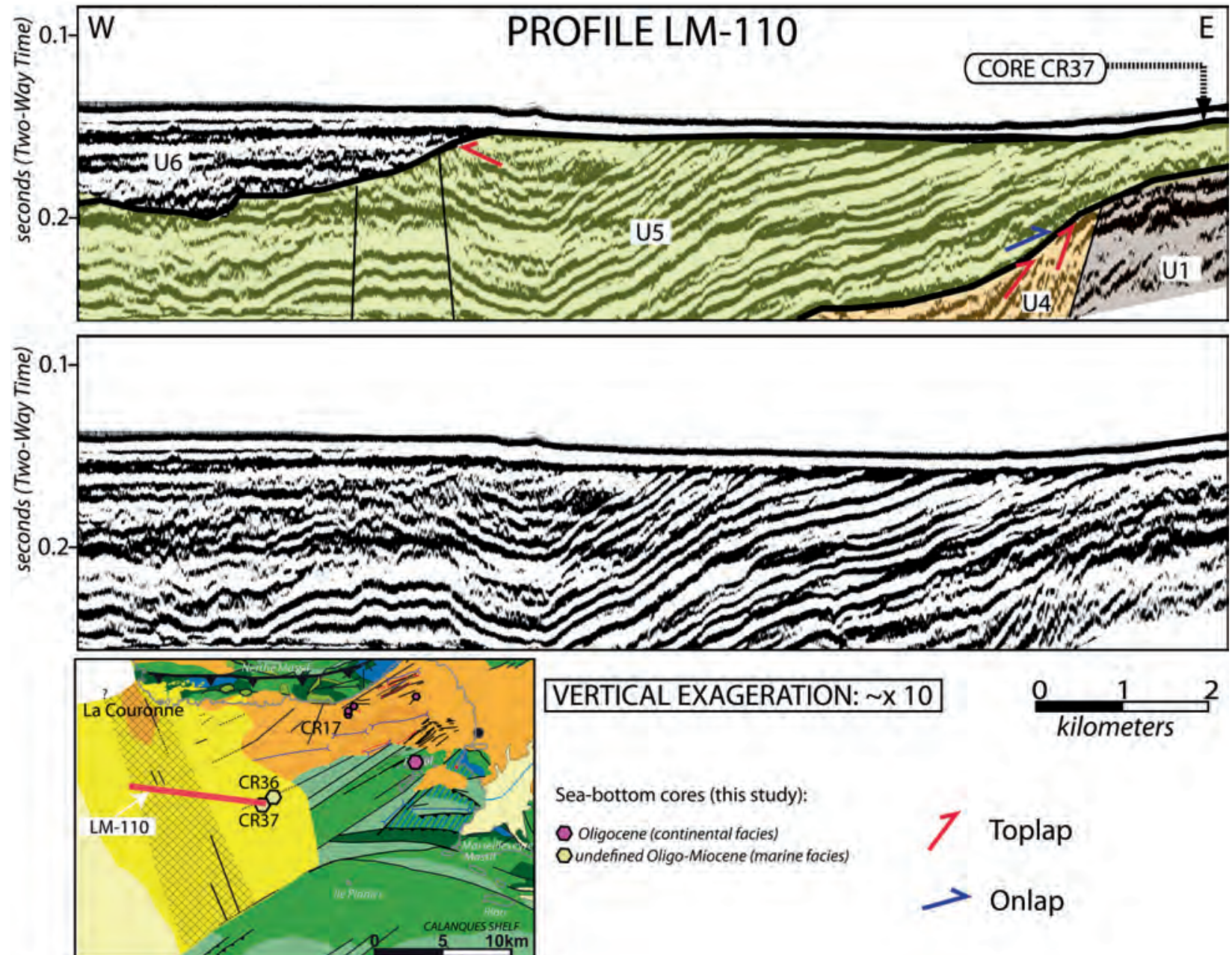

FIG. 20. - HR airgun seismic image and interpretation of profile LM110, located west of the Bay of Marseille (see location in fig. 1 and 21). U1: Aptian-Albian; U4: syn-rift to early post-rift (Chattian to early Burdigalian); U5: post-rift (mid-Burdigalian to Messinian); U6: Plio-Quaternary.

\section{The Calanques shelf}

The Calanques shelf is located south of Planier island and the Calanques coastline, east of the Marseillais canyon and west of the Cassidaigne canyon (fig. 2). South of the Calanques coastline, the Cretaceous sedimentary cover (units U0, U1 and U2) is highly deformed and affected by subvertical faults with orientations ranging from N100 to N120, sealed by Neogene post-rift deposits (unit U5). South of the Riou island, a thick interval (at least $1500 \mathrm{~m}$ ) of Aptian-Albian (Unit U1) and unconformably overlying Upper Cretaceous deposits (Unit U2) is preserved along the axis of a N070-trending syncline (fig. 4). The southern margin of the continental shelf consists of a horst structure bounded by N100 normal faults and composed of Paleozoic metamorphic rocks onlapped by post-rift deposits (Unit U5).

\section{The Blauquières bank and the Cassidaigne canyon}

The Blauquières bank and the Cassidaigne canyon represent the western seaward extension of the Sicié massif that consists of a Paleozoic metamorphic basement overlain by a
Carboniferous to Jurassic sedimentary cover (SiciéBlauquières unit). The Blauquières bank is affected by a set of canyons which are assigned to the Messinian erosional event [Tassy, 2012; Tassy et al., 2014] and which deeply incise the Paleozoic and Mesozoic sedimentary cover as well as the metamorphic basement (fig. 4). The two main incisions are merging into one single N080 oriented canyon (Blauquières canyon) and are filled with Pliocene deposits (up to $600 \mathrm{~m}$ thick) (fig. 2 and fig. 4). The modern Cassidaigne canyon may be regarded as a relict portion of the syn-MSC Blauquières canyon that has not been entirely filled by Plio-Quaternary deposits [Tassy, 2012; Tassy et al., 2014]. South of the Blauquières bank, Neogene post-rift deposits (U5 unit) onlap the metamorphic basement, along the shelf break (fig. 2).

\section{Seaward extension of the Beausset syncline}

Cretaceous deposits of the Beausset syncline (fig. 1) are correctly imaged in sparker profiles from Cassis to Saint-Cyr-sur-Mer (fig. 2). In the Cassis bay, Aptian deposits (Unit U1) conformably overly the Urgonian limestone (top of unit U0) and the unconformable contact between 


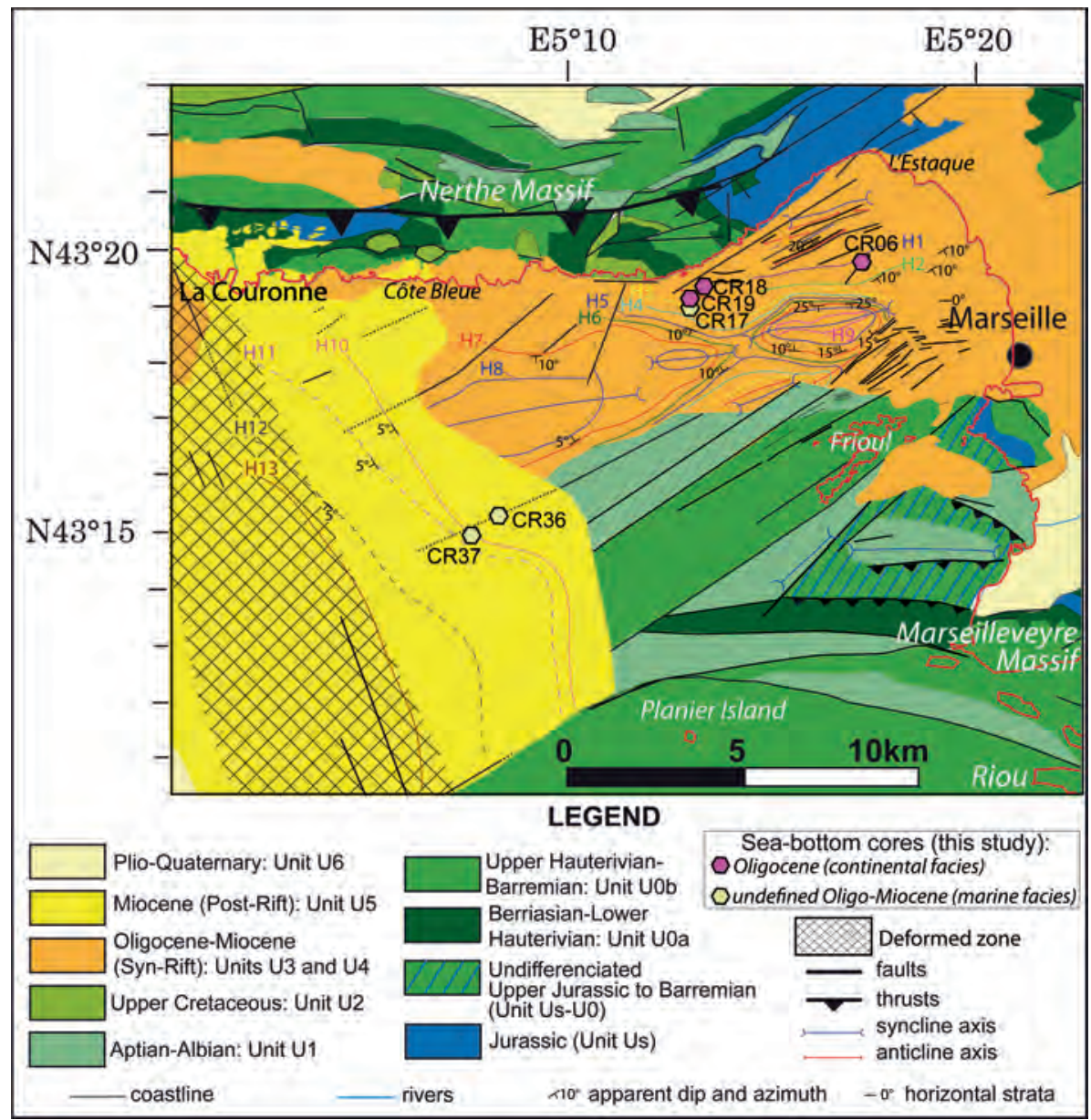

FIG. 21. - Offshore geological map of the bay of Marseille with location of the seismic profiles figured in the present paper. H1 to H13: intersection of selected seismic horizons with the sea bottom.

Aptian marls and overlying Cenomanian quartzone calcarenite is well expressed (fig. 7). Westward between the Calanques coastline and La Ciotat, the seaward extension the Beausset syncline terminates against a nearly vertical N120 fault, which is connected onshore to the N-S trending Luminy fault system (fig. 2). South of La Ciotat, the Beausset syncline ends against the Triassic and Jurassic cover of the Bandol thrust belt. In La Ciotat bay, as evidenced onshore [Philip, 1967, 1982; Philip et al., 1987] the Upper Cretaceous unit (unit U2) from Le Beausset syncline may be overthrusted to the north by the Mesozoic cover of the Bandol thrust belt (fig. 3A) or may passively onlap the Triassic basement (fig. 3B).

\section{DISCUSSION}

\section{New insights into the mid and late Cretaceous paleogeography and structures of Provence}

The seismic interpretation of offshore profiles provides new constraints on the paleogeography of Provence during mid and late Cretaceous times. In figure 23 are mapped the occurrence and associated thickness of Aptian-Albian deposits (U1 unit) on the continental shelf. A key feature of the offshore seismic stratigraphy of Cretaceous series is the remarkable development of Aptian-Albian deposits in the bay of Marseille (up to $0.8 \mathrm{~s}$ two-way time thickness $=1400$ to $2000 \mathrm{~m}$ depth converted thickness: fig. $24 \mathrm{a}$ and b) and south of the Riou island (up to $0.6 \mathrm{~s}$ two-way time thickness $=1000$ to $1500 \mathrm{~m}$ depth converted thickness: fig. 24c). The occurrence and regional distribution of thick Aptian-Albian deposits on the Provence continental shelf may be interpreted as resulting from various tectono-stratigraphic controls. An early, syn-depositional control on the U1 unit thickness is the southward increase in subsidence rate related to the formation of the Aptian-Albian South-Provence basin [Masse and Fenerci-Masse, 2013] that may have resulted in thicker deposition offshore. During the Durancian phase, differential uplift within the Provence area led to partial or complete erosion of the Aptian-Albian deposits. Onshore Albian deposits are reported only near Toulon [Macchour, 1988] and in scattered, small-scale outcrops around Marseille especially in La Nerthe massif. The effect of Durancian differential uplift on the preservation of lower Cretaceous deposits has been evidenced onshore in the Allauch massif [Guillonnet-Benaize et al., 2010] and La Nerthe massif [Masse, 1976]. Offshore, such differential uplift is suspected between La Nerthe massif coast where 
the Aptian deposits are relatively thin $(<150 \mathrm{~m})$ and capped by Upper Cretaceous formations and offshore where U1 unit is extremely thick (>1400 m) (fig. 23). The boundary between thin and thick Aptian-Albian domains is a N090 to N070 normal fault that is sealed by Tertiary deposits (fig. 9 and 23). This accident may have been active during the deposition of unit U1 as suggested by the overall E-W direction that is consistent with the orientation of the Aptian-Albian basin [Masse and Fenerci-Masse, 2013] and by the increase in unit U1 thickness toward the fault (fig. 9 and 24b). On the Calanque shelf, the thickness of Aptian-Albian deposits ranges from $150 \mathrm{~m}$ in the bay of Cassis to $1000-1500 \mathrm{~m}$ (0.6 s TWT) south of Riou island within a distance of less than $8 \mathrm{~km}$ (fig. 24c). Such an increase in thickness may have been driven by syndepositional movement of a set of N090 to N110 normal faults evidenced from seismic data (fig. 23). Such faults have been probably reactivated as normal faults during the Durancian high event, as normal and/or strike slip faults during the late Cretaceous South-Provence basin formation and finally as strike-slip or reverse faults during the Pyreneo-Provençal compression as suggested by the deformation (folds and thrusts) of Lower Cretaceous formations along N110 faults on the Riou island [Monteau et al., 2005]. South of the Riou island, Aptian-Albian deposits are preserved in an E-W-trending syncline of probable Pyreneo-Provençal origin (fig. 24c).

A major issue of the seismic interpretation of the newly acquired seismic data is the mapping of the offshore termination of the Pyreneo-Provençal Sicié imbricate (fig. 2 and 23). The development of the Sicié imbricate led to substantial subsequent erosion of the whole or part of the Mesozoic sedimentary cover. As a consequence, no Cretaceous deposit is preserved on top of the Sicié imbricate in contrast to the Calanques shelf area, west of the Cassidaigne canyon.

On the Provence continental shelf, Upper Cretaceous deposits (U2 unit) are only preserved in the Riou syncline (fig. 11) and in the bay of Marseille (fig. 9) where they reach a thickness of approximately $1000-1500 \mathrm{~m}(0.6 \mathrm{~s}$ TWT). Such a thickness is consistent with the development of a subsiding South-Provence basin [Philip, 1970; Hennuy, 2003] during the Upper Cretaceous at the present-day continental shelf location. The Upper Cretaceous South-Provence basin has been interpreted to result from E-W strike-slip fault movements under a transtensional tectonic regime [Hennuy, 2003]. The studied seismic and core database evidenced that Paleozoic formations are present $8 \mathrm{~km}$ south of La Ciotat coast, and belong to the offshore extension of the Sicié imbricate. Most of the detrital grains within Upper Cretaceous deposits from the South-Provence basin are considered to be sourced from an emerged land located to south, the so-called Massif méridional [Hennuy, 2003], and are of similar composition to that of the Paleozoic metamorphic and sedimentary rocks from the Sicié cape [Redondo, 1986; Guieu et al., 1987]. The depositional dips of the prograding gilbert-delta foresets outcropping along coastal cliffs near La Ciotat, the dominant grain size and the estimated paleo-water-depth at the bottomset location suggest that the top of the foreset is located between 2 and $5 \mathrm{~km}$ south of La Ciotat cliffs [Hennuy, 2003]. Bestani et al. [2015] estimated that prior to the Pyreneo-Provençal shortening, the Sicié imbricate location was shifted 12 kilometers southward relatively to the Mesozoic cover from Le
Beausset unit. As a consequence, the restored position of the Paleozoic submarine outcrops relatively to La Ciotat Upper Cretaceous deltaic foresets $(\sim 20 \mathrm{~km}$ southward from the coast) is consistent with the occurrence, at short distance, of a metamorphic massif as suggested by Hennuy [2003]. The Sicié imbricate may therefore be regarded as a displaced relict of the Upper Cretaceous Massif méridional and the source for terrigenous supplies in the South-Provence basin should be located at least $20 \mathrm{~km}$ south of La Ciotat cliffs.

\section{Evidences and timing of post-rift deformation of the Provence continental shelf}

On the Provence continental shelf, Oligocene and Lower Miocene deposits (units U3 and U4) exhibit evidences of syn-sedimentary and post-sedimentary deformations. Syn-sedimentary deformations consist of dominant NE-SW (N040 to N060) vertical faults and N050 drag-synclines and anticlines (fig. 8) whereas post-depositional deformations include N080-trending en echelon folds (fig. 13) and minor folds and faults localized along a N160 corridor south of La Couronne (fig. 18). Both N080 en echelon folds within the bay of Marseille, and localized deformation along N160 faults south of La Couronne, are sealed by the post-rift U5 unit (fig. 21). The correlations between coastal outcrops and offshore seismic profiles indicate that the top U4 unconformity would correspond to the major angular unconformity evidenced by Oudet et al. [2010] and Demory et al. [2011] at the base of the Plan de Sausset unit (fig. 14) whose age is mid-Burdigalian (NN3 calcareous nannofossil zone). Magnetostratigraphic and biostratigraphic studies [Oudet et al., 2010; Demory et al., 2011] have shown that such an unconformity would correspond to a time hiatus of approximately $2 \mathrm{~m}$.y. (fig. 25), including part of the early and mid Burdigalian (20-18 Ma). Units U3 and U4 are crosscut by normal faults of dominant NE-SW orientation that is consistent with the orientation of the major L'Estaque and L'Amandier fault systems (fig. 2 and 26) identified onshore in the Oligocene Marseille basin [Nury and Raynaud, 1986; Hippolyte et al., 1991]. As suggested by the occurrence of N050 syn-sedimentary folds northwest of the Frioul islands, N050 normal faults were active during the syn-rift phase. A large part of the normal faults affecting U3 and U4 units are sealed by the post-rift U5 unit (fig. 16, 18, 19). As evidenced by Hippolyte et al. [1991], the major NE-SW (N040 to N060) normal faults have formed during the early stages of extension (Rupelian) of the Oligocene Marseille basin. The occurrence of N080 en echelon folds in the bay of Marseille is consistent with a sinistral strike-slip reactivation of the N040 to N060 faults during a compressive phase of N-S direction (fig. 26). Such a post-rift, N-S compressive phase with sinistral strike-slip reactivation of N020 to N060 faults has been evidenced onshore in the Oligocene Marseille basin by microstructural analyses [Nury and Raynaud, 1986]. The age of this N-S compression phase is estimated to range from the early to mid Burdigalian (20-18 Ma) as suggested by the time gap evidenced between top U4 and base U5 unit (fig. 25).

The deformation along the N160 corridor south of La Couronne is polyphased. The angular unconformity between U4 and U5 units suggest a first phase of deformation that is coeval with the en echelon folds development and probably related to a minor dextral strike slip reactivation 


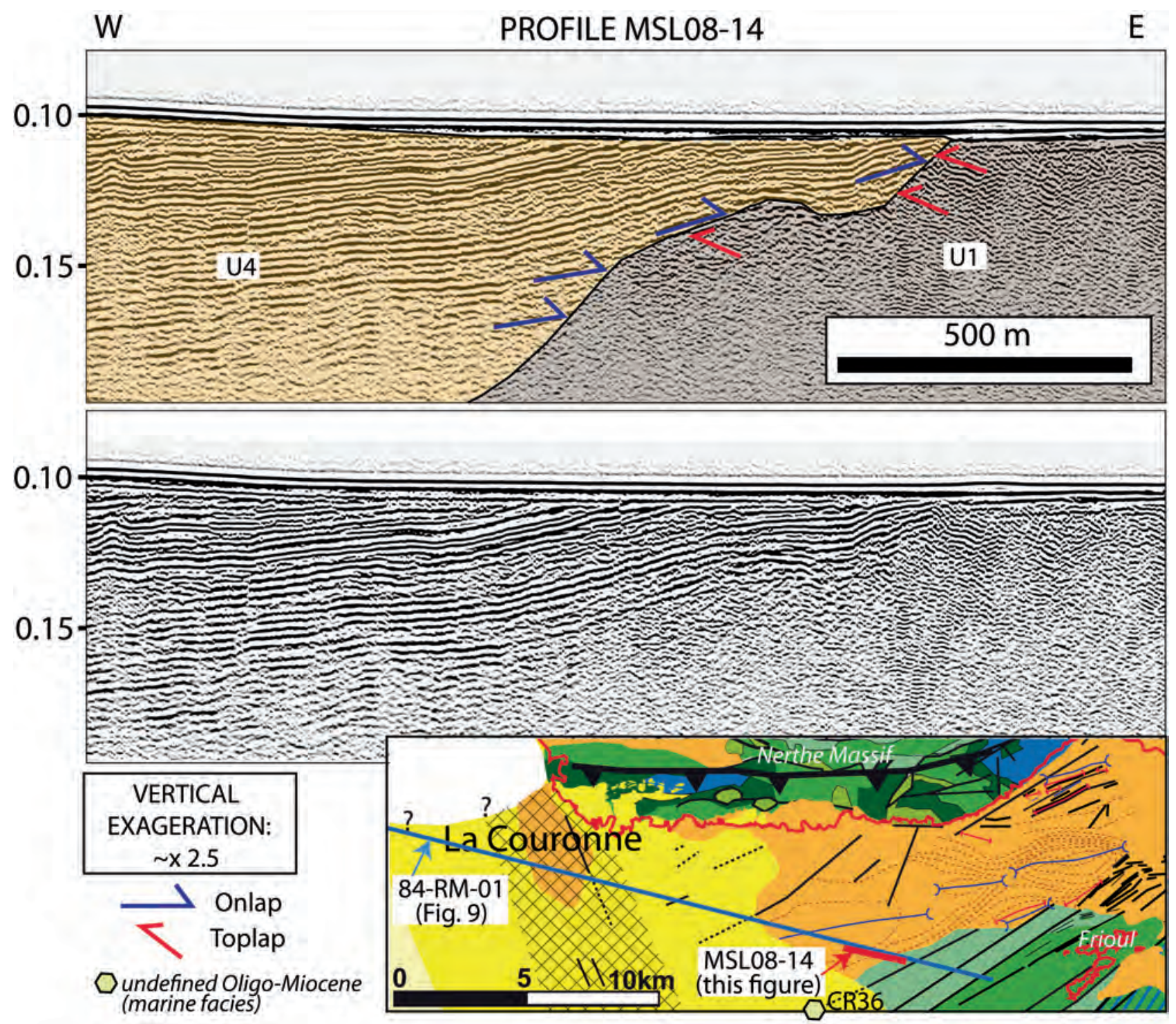

FIG. 22. - VHR sparker seismic image and interpretation of profile MSL08-14, located on the southern margin of the Oligo-Miocene Marseille extensional basin (see location in fig. 1 and 21). U1: Aptian-Albian; U4: syn-rift to early post-rift (Chattian to early Burdigalian).

of syn-rift N160 faults in response to the N-S compression. Later deformations affect the U5 unit and consist of N160 fault (strike-slip?) reactivation and localized folding at the vicinity of the faults thus leading to a $5 \mathrm{~km}$ width N160-trending corridor of deformation that is sealed by post-Messinian deposits. Flower-like structures affecting the U5 unit are evidenced southwest of Planier island and are probably related to a reactivation of N050 faults during a post-rift compressive phase. Such deformations suggest one or various post-Burdigalian and pre-Messinian episodes of compression. Onshore Provence, the timing of post-rift deformation is relatively poorly constrained. In northern Provence, the onset of Alpine compressive deformation is recorded by the subsidence inversion in the Valensole area and is believed to start during the Burdigalian times [Dubois and Curnelle, 1978] and to continue until the Langhian [Villeger, 1984]. The age of the beginning of the Alpine deformation (Burdigalian to Langhian) was confirmed by field studies along the Salon-Cavaillon fault [Molliex, 2009; Molliex et al., 2011]. Besson [2005] evidenced, in the whole western Provence area, a network of deeply incised valleys related to a hectometer-scale uplift that occurred during the Burdigalian. The oldest deposits infilling these incisions are mid-Burdigalian (NN3 calcareous nannofossil zone at the base of the sequence S1 of Besson [2005]) and can therefore be correlated with the Plan de Sausset unit from the southern flank of the Nerthe massif, and offshore, with the base of the U5 unit. The regional uplift recorded onshore by the Burdigalian incised valleys (base S1 of Besson [2005]) is therefore probably coeval with the strike-slip reactivation of N040-N060 and N160 faults and the development of en echelon folds in the bay of Marseille. The available chronostratigraphic constraints (fig. 25) indicate that the Burdigalian compression evidenced by seismic data offshore occurred when the counterclockwise rotation velocity of Sardinia with respect to stable Eurasia started to 


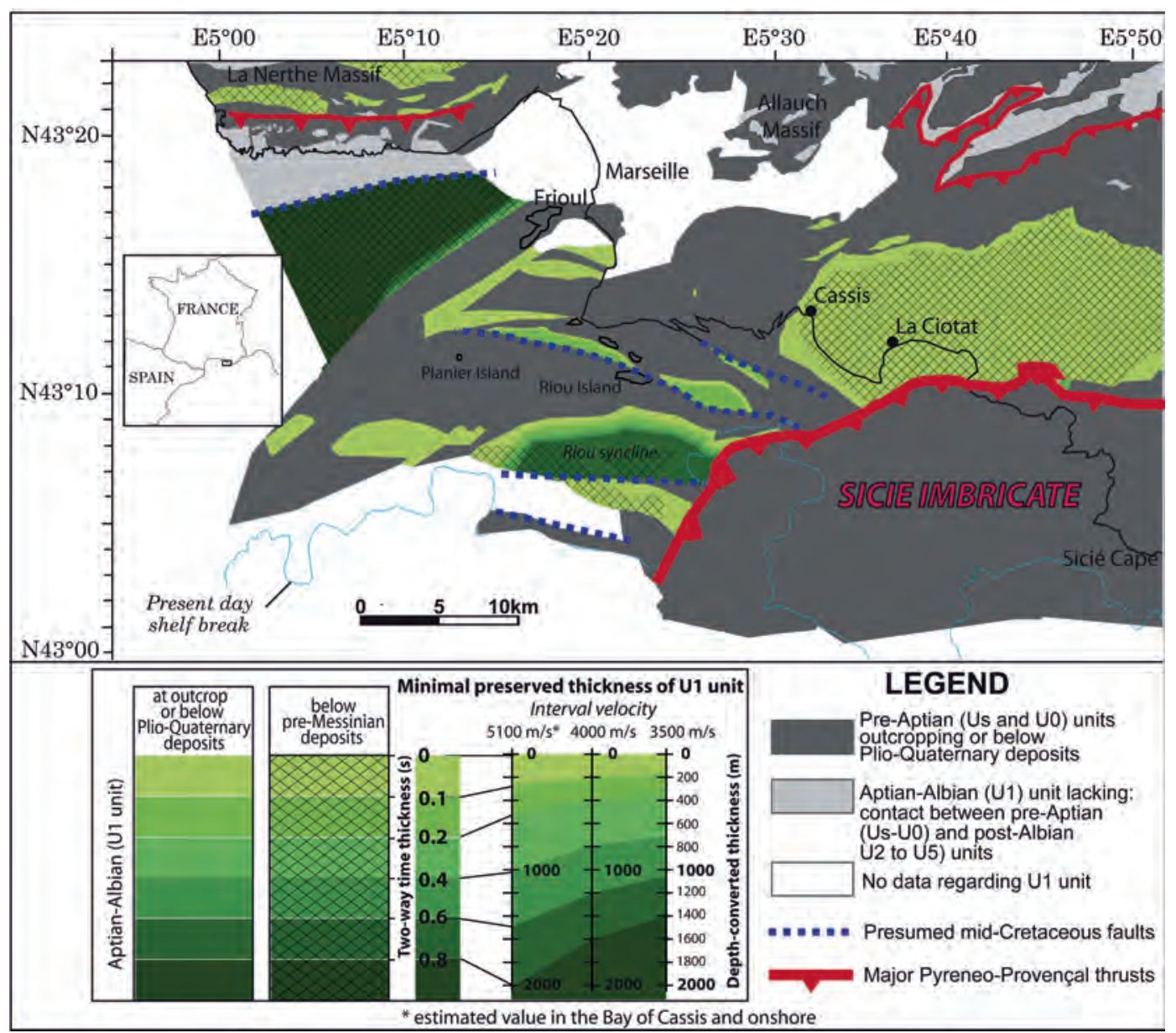

FIG. 23. - Onshore and offshore occurrence and thickness of Aptian-Albian deposits with indication of presumed mid-Cretaceous faults and major Pyreneo-Provençal thrusts.

decrease (i.e. around the inflexion point of the Sardinia rotation angle through times), at least $3 \mathrm{Ma}$ before the end of the rotation of Sardinia (15 Ma after Gattacceca et al. [2007]). Such a timing suggests therefore that the southward propagation of the Alpine thrust front started prior to the end of the Liguro-Provençal oceanic opening. The age of the later deformations affecting the U5 unit is poorly constrained: they occurred during or after the Burdigalian and before the MSC. Such deformations may be assigned to the Tortonian compressive phase that is well expressed onshore between the Salon-Cavaillon and Mid-Durance faults [Clauzon, 1984, 1988] and that is believed to be responsible for the reactivation of older structures such as the Concors anticlines [Clauzon et al., 2011] and for the formation of $\mathrm{La}$ Trevaresse massif [Chardon and Bellier, 2003] (fig. 24a).

\section{CONCLUSION}

The integrative interpretation of marine seismic and sea-bottom rock samples provides new insights into the structural and paleogeographic framework of post-Jurassic series of the Provence continental shelf. Seven major post-Jurassic seismic units have been defined from marine seismic data and a geological map of the Provence shelf has been produced. The major results of the present study regarding the mid and late Cretaceous paleogeography and structural framework are:

1) the occurrence offshore of a thick (up to $2000 \mathrm{~m}$ ) Aptian-Albian deposition controlled by E-W-trending normal faults. Such deposits are preserved within Pyreneo-Provençal synclines or within Oligo-Miocene grabens;

2) the occurrence of thick Upper Cretaceous series (up to $1500 \mathrm{~m}$ ) confirms the existence of an E-W elongated South-Provence through during Cenomanian to Santonian times;

3) the Sicié imbricate is a major Pyreneo-Provençal structure recognized on the Provence continental shelf. Its western boundary is located west of the Cassidaigne canyon. The Paleozoic metamorphic basement and its Mesozoic sedimentary cover is regarded as the displaced relict of the Upper Cretaceous "Massif méridional" that represents the main source of terrigenous sediments in the South-Provence basin.

These results show that quantitative structural restorations of the basement and sedimentary cover are essential for further reconstructions of a detailed and accurate paleogeographic setting of pre-Pyreneo-Provençal depositional systems.

In addition the present study provided evidences of syn-rift and post-rift deformations on the Provence continental shelf: 


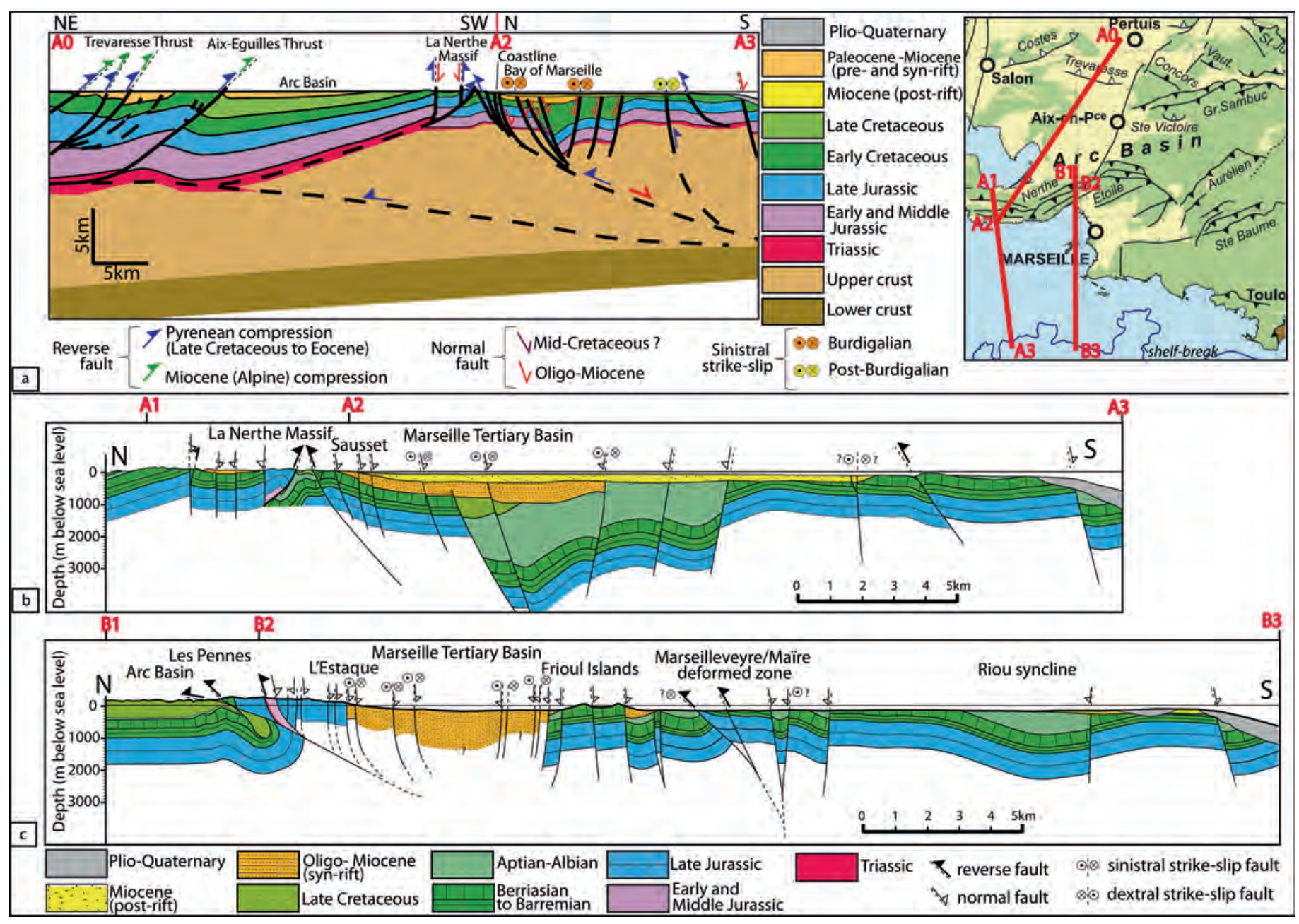

FIG. 24. - a) Interpretative crustal-scale cross section summarizing the in-depth interpretations of the southern Provence area; onshore structures and interpretations are compiled from Lacombe and Jolivet [2005], Terrier et al. [2008], Molliex et al. [2011] and Andreani et al. [2013]. b) Geological cross-section across the Nerthe range onshore (modified from Andreani et al. [2013]) and the Provence continental shelf offshore (from the present database). c) Geological cross-section across the western Etoile range onshore (modified from Andreani et al. [2010]) and the Provence continental shelf offshore (from the present database). For b) and c) detailed location is shown on figure 2.

4) during the rifting phase, syn-sedimentary deformations consist of dominant NE-SW (N040 to N060) vertical fault development and N050 drag-syncline and anticline formation;

5) in the bay of Marseille, the syn-rift and early post-rift deposits (U3 and U4 units: Rupelian to early Burdigalian) are structured into a set of E-W-trending en echelon folds that are interpreted to result from sinistral strike-slip reactivation of the NE-SW faults during a N-S compressive phase of early-to-mid Burdigalian age (18-20 Ma);

6) the Burdigalian compressive event recorded on the Provence continental shelf is coeval with the regional uplift recorded onshore by the Burdigalian incised valleys (base S1 of Besson [2005]);
7) minor deformations affect the post-rift U5 unit (mid Burdigalian to Messinian), particularly along a N160-trending corridor localized south of La Couronne. Such deformations are interpreted as resulting from a later, post-Burdigalian and pre-Messinian compressive phase.

Acknowledgements. - This work was funded by Action Marges and KarstEAU project. Authors thank the captains and the crew of the R/V TETHYS II ship. We particularly thank Jacques Bégot (IUEM Brest) and Fabien Paquet (BRGM) for their technical support on seismic acquisition. We would like to thank the Master SET students (Aix-Marseille University) for their contribution to the seismic acquisition in 2007 and 2009 (LM5913 surveys). We also thank S. Berné for providing seismic lines from the CALMAR cruise and IFREMER for the MARION profile.

SGF associate editor: Philippe Yamato 


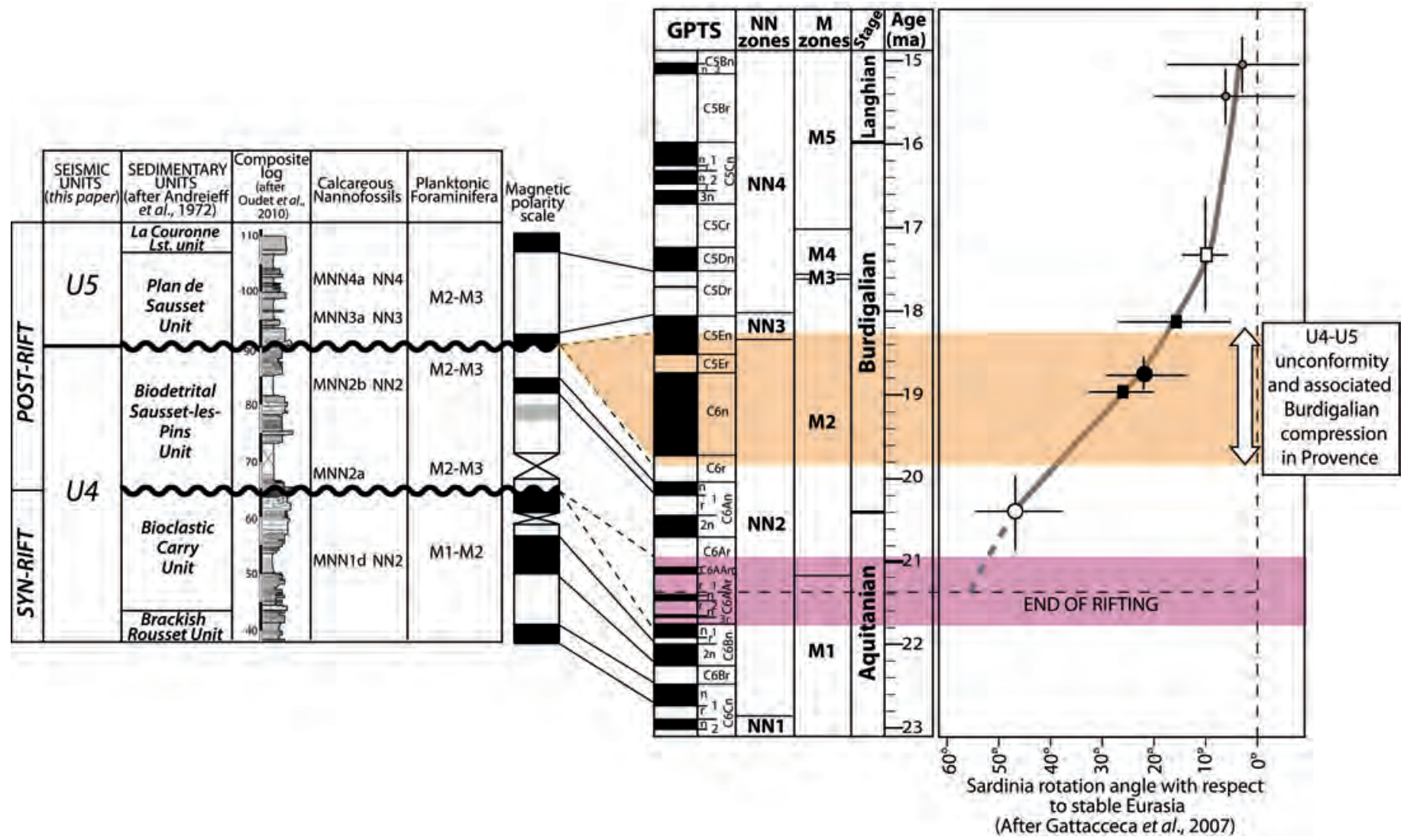

FIG. 25. - Chronostratigraphic constraints of the U4 (syn-rift to early post-rift) and U5 (later post-rift). Such chronostratigraphic framework is compared with the evolution of the Liguro-Provençal basin and associated rotation of Sardinia with respect to stable Eurasia [after Gattacceca et al., 2007]

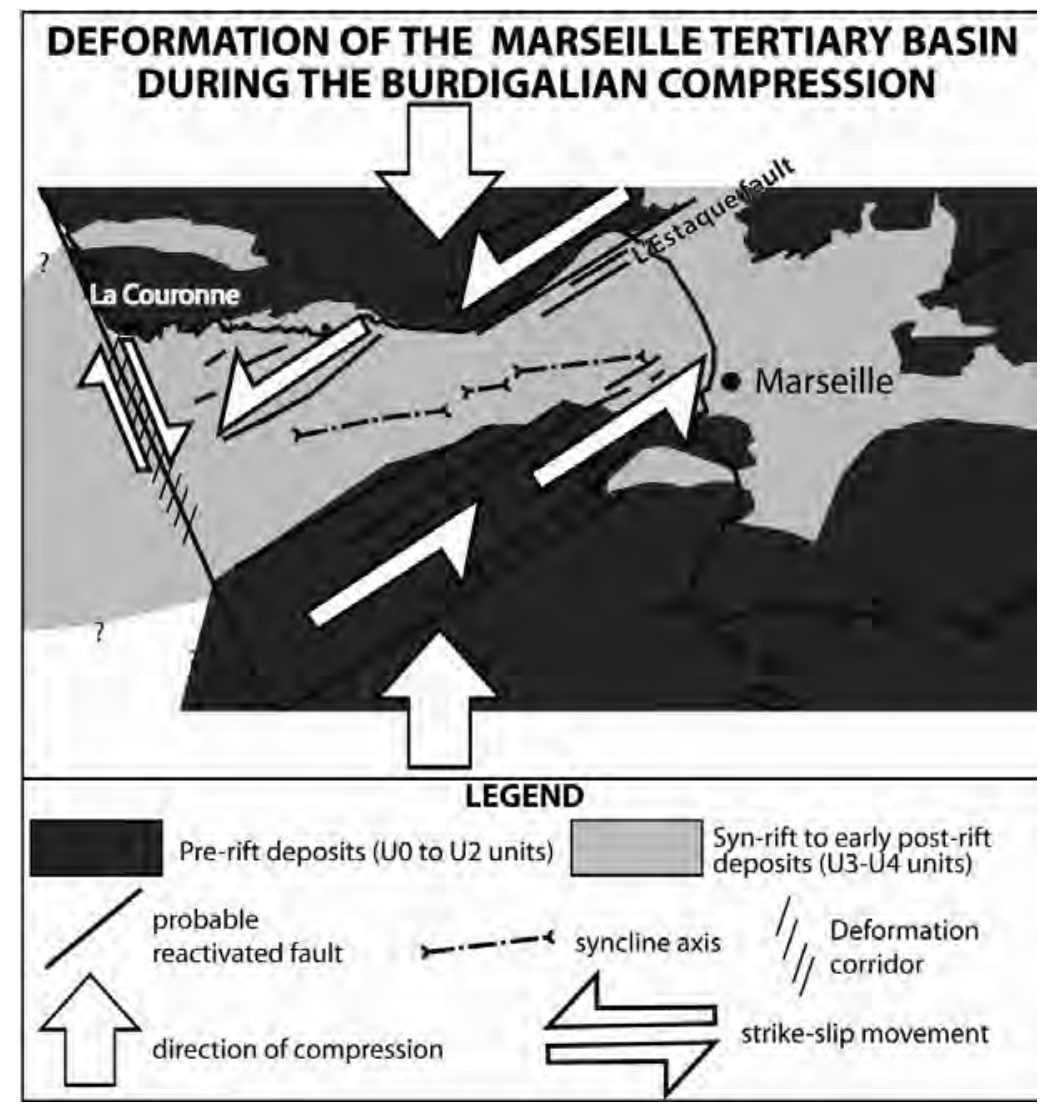

FIG. 26. - Sketch of the deformation of the Tertiary Marseille basin during the Burdigalian compression. 


\section{References}

Andreani L., Loget N., Rangin C. \& Le Pichon X. (2010). - New structural constraints on the southern Provence thrust belt (France): evidences for an Eocene shortening event linked to the Corsica-Sardinia subduction. In: X. Le Pichon and C. RAngin, Eds, Geodynamics of the France Southeast Basin. - Bulletin de la Société géologique de France, 181, 6, 547-563.

Andreani L., Loget N., Rangin C. \& Le Pichon X. (2013). - Reply to the comments of Jean Philip on the paper entitled "New structura constraints on the southern Provence thrust belt (France): evidences for an Eocene shortening event linked to the Corsica-Sardinia subduction". - Bulletin de la Société géologique de France, 184, 3, 279-285.

BACHE F. (2008). - Evolution Oligo-Miocène des marges du micro océan Liguro-Provençal. - PhD thesis, Univ. Bretagne Occidentale, $338 \mathrm{p}$.

Bache F., Olivet J.-L., Gorini C., Rabineau M., Baztan J., Aslanian D. \& Suc J.-P. (2009). - The Messinian erosional and salinity crises: view from the Provence basin (Gulf of Lions, western Mediterranean). - Earth Planetary Science Letters, 286, 139-157.

Bache F., Olivet J.-L., Gorini C., Aslanian D., Labails C. \& Rabineau M. (2010). - Evolution of rifted continental margins: the case of the Gulf of Lions (western Mediterranean basin). - Earth Planetary Science Letters, 292, 345-356.

Bergerat F. (1987). - Paléo-champs de constraintes tertiaires dans la plate-forme européenne au front de l'orogène alpin. - Bulletin de la Société géologique de France, 8, III, 3, 611-620.

BESSON D. (2005). - Architecture du bassin rhodano-provençal miocène (Alpes, SE France): relations entre déformation, physiographie et sédimentation dans un bassin molassique d'avant-pays. - PhD thesis, Ecole Nationale Supérieure des Mines de Paris, 438p.

Bestani L., Espurt N., Lamarche J., Floquet M., Philip J., Bellier O. \& Hollender F. (2015). - Structural style and evolution of the Pyrenean-Provence thrust belt, SE France. - Bulletin de la Société géologique de France, 186, 4-5, 223-241.

Bigot-Cormier F., Sage F., Sosson M., Deverchere J., Ferrandini M., Guennoc P., Popoff M. \& Stephan J.-F. (2004). - Déformations pliocènes de la marge nord-Ligure (France): les conséquences d'un chevauchement crustal sub-alpin. - Bulletin de la Société géologique de France, 175, 197-211.

Blanc J.-J. \& BlanC-VERnEt L. (1966). - Affleurements sous-marins du Barrémien et de l'Aptien dans la baie de Cassis. - Comptes Rendus de l'Académie des Sciences, Paris, 262, 1398-1399.

Blanc J.-J., Froget C. \& Guieu G. (1967). - Géologie littorale et sous-marine de la région de Marseille. Relations avec les structures de Basse-Provence. - Bulletin de la Société géologique de France, IX, 4, 561-571.

BlanC-VERnet L. (1969). - Contributions à l'étude des foraminifères de Méditerranée. - Recueil des Travaux de la Station Marine d'Endoume, 48, 315p.

BlEs J.-L. \& GROS Y. (1991). - Stress field changes in the Rhône valley from the Miocene to the present. - Tectonophysics, 194, 265-277.

Bourcart J. (1949). - Peut-on étudier directement la géologie du plateau continental? - Comptes-Rendus de la Société géologique de France, 2, 12-14.

Bourcart J. (1960). - Carte topographique du fond de la Méditerranée occidentale. - Bulletin du Musée Océanographique de Monaco, 1163, 20p.

Carminati E., Wortel M.J.R., Meijer P.T. \& SAbadini R. (1998a). - The two-stage opening of the western-central Mediterranean basins: a forward modeling test to a new evolutionary model. - Earth Planetary Science Letters, 160, 667-679.

Carminati E., Wortel M.J.R., Spakman W. \& Sabadini R. (1998b). - The role of slab detachment processes in the opening of the western-central Mediterranean basins: some geological and geophysical evidence. - Earth Planetary Science Letters, 160, 651-665.

Champion C., Choukroune P. \& Clauzon G. (2000). - La déformation post-Miocène en Provence occidentale. - Geodinamica Acta, 13, 67-85.
Chardon C. \& Bellier O. (2003). - Geological boundary conditions of the 1909 Lambesc (Provence, France) earthquake: Structure and evolution of the Trévaresse ridge anticline. - Bulletin de la Société géologique de France, 174, 5, 497-510.

Clauzon G. (1984). - Evolution géodynamique d'une montagne provençale et de son piedmont: l'exemple du Luberon (Vaucluse, France). - Montagnes et Piémonts, Toulouse, R.G.P.S.O.

Clauzon G. (1988). - Evolution géodynamique pliocène du bassin de $\mathrm{Cu}$ curon/Basse-Durance (Provence, France): une megaséquence régressive de comblement d'une ria méditerranéenne consécutive à la crise de salinité messinienne. - Géologie Alpine, Mém. H.S. 14, 215-226.

Clauzon G., Fleury T.-J., Bellier O., Molliex S., Mocochain L. \& Aguilar J.-P. (2011). - Morphostructural evolution of the Luberon since the Miocene (SE France). - Bulletin de la Société géologique de France, 182, 2, 95-110.

Collina-GiRARD J. (1992). - Présentation d'une carte bathymétrique au $1 / 25000^{\circ}$ du Précontinent Marseillais (au large de la zone limitée par la grotte Cosquer et l'habitat préhistorique de Carry le Rouet). - Géologie Méditerranéenne, XIX, 2, 77-97.

CollinA-Girard J. (1997). - Profils littoraux en plongée et niveaux d'érosion eustatique près de la grotte Cosquer (Marseille) et en Provence. - Comptes-Rendus de l'Académie des Sciences, Paris, 324, IIa, 607-615.

Coulon C. (1967). - Le volcanisme tertiaire de la région toulonnaise (Var). Bulletin de la Société géologique de France, IX, 7, 691-700.

Demory F., Conesa G., Oudet J., Mansour H., Münch P., Borgomano J., Thouveny N., Lamarche J., Gisouet F. \& Marie L. (2011). Magnetostratigraphy and paleoenvironments in shallow-water carbonates: the Oligocene-Miocene sediments of the northern margin of the Liguro-Provençal basin (West Marseille, southeastern France). - Bulletin de la Société géologique de France, 182 $1,37-55$.

Dercourt J., Zonenshain L.P., Ricou L.-E., Kasmin V.G., Le Pichon X., Knipper A.L., Grandjacouet C., Sbortshikov I.M., Geyssant J., Lepvrier C., Pechersky D.H., Boulin J., Sibuet J.-C., Savostin L.A., Sorokhtin O., Westphal M., Bazhenov M.L., LAVEZ J.-P. \& BiJu-Duval B. (1986). - Geological evolution of the Tethys belt from Atlantic to Pamirs since the Lias. - Tectonophysics, 123, 241-315.

Dos ReIS T. (2001). - La tectonique salifère et son influence sur l'architecture sédimentaire quaternaire de la marge du golfe du Lion-Méditerranée occidentale. $-\mathrm{PhD}$ thesis, Univ. Paris 6, 216 p. +157 pp.

Dubois P. \& CuRnelle R. (1978). - Résultats apportés par le forage Les Mées-1 sur le plateau de Valensole. - Comptes-Rendus Sommaire de la Société géologique de France, 4, 181-184.

Ducrot J. (1967). - Premières données sur la structure profonde du banc des Blauquières (région de la Ciotat, Bouches-du-Rhône). Comptes-Rendus Sommaire de la Société géologique de France, 3, 80 .

Floquet M. \& Hennuy J. (2003). - Evolutionary gravity flow deposits in the Middle Turonian-Early Coniacian southern Provence basin (SE France): origins and depositional processes. In: J. LOCAT \& J. Mienert, Eds., Submarine mass movements and their consequences. - Kluwer Academic Publishers, Dordrecht, The Netherlands, 417-424.

Floquet M., Gari J., Hennuy J., Leonide P. \& Philip J. (2005). - Sédimentations gravitaires carbonatées et silicoclastiques dans un bassin en transtension, séries d'âge cénomanien à coniacien moyen du Bassin Sud-Provençal. - 10ème Congrès Français de Sédimentologie, Publ. ASF, 52, Paris, Giens, 80p.

Floquet M., Philip J., Leonide P. \& Gari J. (2006). - Sédimentation et géodynamique du bassin Sud-Provençal au Crétacé supérieur, histoire et dynamique des plates-formes carbonatées et de leur biotas durant le Phanérozoïque. - Réunion spécialisée de la Société géologique de France: Histoire et dynamique des plates-formes carbonatées et de leurs biotas durant le Phanérozoüque-Journées Jean Philip, Université de Provence, Marseille, $69 \mathrm{p}$. 
Fournier F., Leonide P., Biscarrat K., Gallois A., Borgomano J. \& FouberT A. (2011). - Elastic properties of microporous cemented grainstones. - Geophysics, 76, 6, 211-226.

FourniLlon A. (2013). - Modélisation géologique 3D et hydrodynamique appliquées aux réservoirs carbonatés karstiques: caractérisation des ressources en eau souterraine de l'unité du Beausset (SE France). - PhD thesis, Aix-Marseille Univ., 428p.

Froget C. (1967). - Découvertes d'affleurements quaternaires anciens sur le Précontinent provençal au large de l'île de Riou. - Comptes Rendus de l'Académie des Sciences, Paris, (D), 264, 2, 212-214.

Froget C. (1971). - Etat sur les connaissances du canyon de Cassidaigne et de ses abords (sud de Cassis, Bouches-du-Rhône). - Bulletin du BRGM, section IV, Géologie Générale, 3, 5-13.

Froget C. (1972). - Exemples de diagenèse sous-marine dans les sédiments pliocènes et pléistocènes: dolomitization, ferruginisation (Méditerranée nordoccidentale, sud de Marseille). Examples of submarine diagenesis in Pliocene and Pleistocene sediments: dolomitization, ferruginisation (northwest Mediterranean, south of Marseille). - Sedimentology, 19, 59-83.

Froget C. (1974). - Essai sur la géologie du pré-continent de la Provence occidentale. - PhD thesis, Aix-Marseille Univ., 219 p.

Gattacceca J., Deino A., Rizzo R., Jones D.S., Henry B., Beaudoin B. \& VADEBoIn F. (2007). - Miocene rotation of Sardinia: New paleomagnetic and geochronological constraints and geodynamic implications. - Earth Planetary Science Letters, 258, 359-377.

Gignoux M. (1925). - Géologie stratigraphique. - Masson et Cie, Paris.

Gorini C., Le Marrec A. \& Mauffret A. (1993). - Contribution to the structural and sedimentary history of the Gulf of Lions (western Mediterranean), from the ECORS profiles, industrial seismic profiles and well data. - Bulletin de la Société géologique de France, 164, 353-363.

Graciansky P.-C. DE \& Lemoine M. (1988). - Early Cretaceous tectonics in the southwestern French Alps: a consequence of North-Atlantic rifting during Tethyan spreading. - Bulletin de la Société géologique de France, 8, IV, 5, 733-737.

Gueguen E., Doglioni C. \& Fernandez M. (1998). - On the post 25 Ma geodynamic evolution of the western Mediterranean. - Tectonophysics, 298, 259-269.

Guennoc P., Gorini C. \& Mauffret A. (2000). - Histoire géologique du golfe du Lion et cartographie du rift oligo-aquitanien et de la surface messinienne. - Géologie de la France, 3, 67-97.

GiEu G. (1968). - Etude tectonique de la région de Marseille. - Thèse d'Etat, Université Aix Marseille I, 604p.

Guieu G., Philip J., Durand J.-P., Nury D. \& Redondo C. (1987). - Le détritisme provençal du Crétacé moyen à l'Oligocène dans son cadre paleogéographique, structural et géodynamique. - Géologie Alpine, Mém. h. s., 13, 247-271.

Guignard P., Bellier O. \& Chardon D. (2005). - Géométrie et cinématique post-oligocène des failles d'Aix et de la moyenne Durance (Provence, France). - Comptes-Rendus Géosciences, 337, 3, 375-384.

Guyonnet-Benaize C., Lamarche J., Masse J.-P., Villeneuve M. \& VISEUR S. (2010). - 3D structural modelling of small deformations in polyphase faults pattern; application to the Mid-Cretaceous Durance uplift, Provence (SE France). - Journal of Geodynamics, 50, 2, 81-93.

HenNuY J. (2003). - Sédimentation carbonatée et silicoclastique sous contrôle tectonique, le bassin Sud-Provençal et sa plate-forme carbonatée du Turonien moyen au Coniacien moyen - Evolution séquentielle, diagénetique, paléogéographique. - PhD Thesis, Université de Provence, Marseille, 208 p.

Hippolyte J.-C., Nury D., Angelier J. \& Bergerat F. (1991). - Relations entre tectonique extensive et sédimentation continentale: exemple des oligocènes de Marseille et de Basse-Provence. Bulletin de la Société géologique de France, 162, 6, 1083-1094.

Hippolyte J.-C., Angelier J., Bergerat F., Nury D. \& Guieu G. (1993). Tectonic-stratigraphic record of paleostress time changes in the Oligocene basins of the Provence, southern France. - Tectonophysics, 226, 15-35

Hsü K.J. (1973). - The desiccated deep-basin model for the Messinian events. In: C.W. Drooger, Ed., Messinian events in the Mediterranean. - North-Holland Publ. Co., Amsterdam, 60-67.
Jolet P. (1996). - Etude stratigraphique et sédimentologique d'une plate-forme mixte carbonatée-silicoclastique: le Turonien de Provence (S.E. France). - PhD Thesis, Aix-Marseille Univ., $221 \mathrm{p}$.

Jolivet L., Gorini C., Smit J. \& Leroy S. (2015). - Continental breakup and the dynamics of rifting in back-arc basins: The Gulf of Lion margin. - Tectonics, 34, 4, 662-679.

Krijgsman W., Hilgen F.J., Ra I., Sierro F.J. \& Wilson D.S. (1999). Chronology, causes and progression of the Messinian salinity crisis. - Nature, 400, 652-655.

Lacombe O. \& Jolivet L. (2005). - Structural and kinematic relationships between Corsica and the Pyrenees-Provence domain at the time of the Pyrenean orogeny. - Tectonics, 24, TC1003, doi: 10.1029/ 2004 TC001673.

Larroque C., Mercier De Lepinay B. \& Migeon S. (2010). - Morphotectonic and fault-earthquake relationships along the northern Ligurian margin (western Mediterranean) based on high resolution, multibeam bathymetry and multichannel seismic-reflection profiles. - Marine Geophysical Research, 32, 163-179.

Leenhardt O., Pierrot S., Rebufatti A. \& Sabatier H. (1969). - Etude sismique de la zone de Planier (Bouches du Rhône). - Revue de l'Institut Français du Pétrole, XXIV, 11, 1261-1287.

Leleu S., Ghienne J-F. \& Manatschal G. (2009). - Alluvial fan development and morpho-tectonic evolution in response to contractional fault reactivation (Late Cretaceous-Palaeocene), Provence, France. Basin Research, 21, 157-187.

Lofi J., Rabineau M., Gorini C., Berne S., Clauzon G., De Clarens P., Moutain G.S., Ryan W.B.F., Steckler M.S. \& Fouchet C. (2003). - Plio-Quaternary prograding clinoform wedges of the western Gulf of Lions continental margin (NW Mediterranean) after the Messinian Salinity Crisis. - Marine Geology, 198, 3-4, 289-317.

Lofi J., Gorini C., Berne S., Clauzon G., Dos Reis A.T., Ryan W.B.F. \& STECKLER M. (2005). - Paleoenvironmental changes and erosional processes on the western Gulf of Lions during the Messinian Salinity Crisis. - Marine Geology, 217, 1-2, 1-30.

LOFI J. \& BERNE S. (2008). - Evidence for pre-Messinian submarine canyons on the Gulf of Lions slope (western Mediterranean). Marine and Petroleum Geology, 25, 8, 804-817.

Lutaud L. (1935). - Sur la genèse des chevauchements et écailles de la Provence calcaire. - Comptes Rendus Sommaires de la Société géologique de France, 261-263.

Machhour L. (1988). - Le Bassin toulonnais au Crétacé moyen (AptienCénomanien), Sud-Est de la France. - PhD thesis, Université de Provence, 472p.

Manzi V., Gennari R, Hilgen F, Krijgsman W., Lugli S., Roveri M. \& SiERro F.J. (2013). - Age refinement of the Messinian Salinity Crisis onset in the Mediterranean. - Terra Nova, 25, 4, 315-322.

Masse J.-P. (1976). - Les calcaires urgoniens de Provence-Valanginien-Aptien inférieur. - Thèse d'État, Univ. Aix-Marseille II, 3 vol.

MAsse J.-P. \& PhiliP J. (1976). - Paléogéographie et tectonique du Crétacé moyen en Provence. - Revue de Géographie Physique et Géologie Dynamique, 2, 49-66.

Masse J.-P. \& Fenerci-Masse M. (2013). - Drowning events, development and demise of carbonate platforms and controlling factors: The Late Barremian-Early Aptian record of Southeast France. - Sedimentary Geology, 298, 28-52.

Masse J.-P., Villeneuve M., Leonforte E. \& Nizou J. (2009). - Block tilting of the North Provence Early Cretaceous carbonate margin; stratigraphic, sedimentologic and tectonic data. - Bulletin de la Société géologique de France, 180, 2, 105-115.

Mattauer M. (1968). - Les traits structuraux essentiels de la chaîne Pyrénéenne. - Revue de Geologie Dynamique et de Geographie Physique, 10, 3-11.

Mauffret A. \& Gorini C. (1996). - Structural style and geodynamic evolution of Camargue and western Provençal basin, southeastern France. - Tectonics, 15, 356-375.

Mauffret A., Frizon De La Motte D., Lallemant S., Gorini C. \& MailLART A. (2004). - E-W opening of the Algerian basin (western Mediterranean). - Terra Nova, 16, 5, 257-264.

Molliex S. (2009). - Caractérisation de la déformation tectonique récente en Provence (SE France). - PhD thesis, Univ. Aix-Marseille III, 346 p. 
Molliex S., Bellier O, Terrier M., Lamarche J., Martelet G. \& Espurt N. (2011). - Tectonic and sedimentary inheritance on the structural framework of Provence (SE France): Importance of the Salon-Cavaillon fault. - Tectonophysics, 501, 1-16.

Monteau R., Ricour J. \& Argyriadis I. (2005). - Structure chevauchante du massif de Marseilleveyre et de l'archipel Riou-Jaîre-Maïre, à Marseille (Bouches-du-Rhône). - Mésogée, 61, 61-70.

Moulin M., Klingelhoefer F., Afiladho A., Aslanian D., Schnürle P., Nouze H., Beslier M.-O. \& Feld A. (2015). - Deep crustal structure across a young passive margin from wide-angle and reflection seismic data (The SARDINIA Experiment) - I. Gulf of Lion's margin. - Bulletin de la Société géologique de France, 186, 4-5, 309-330.

NURY D. (1988). - L'Oligocène de Provence méridionale: stratigraphie, dynamique sédimentaire, reconstitutions paléogéographiques. PhD thesis, Univ. de Provence, $411 \mathrm{p}$.

NuRY D. \& RAYNAud S. (1986). - Etude tectono-sédimentaire du fossé Oligocène de Marseille (Bouches-du-Rhône). Evolution postérieure. - Géologie de la France, 4, 377-397.

OudET J. (2008). - Etude terre-mer de la transition syn-rift/post-rift sur les marges de l'océan Liguro-Provençal: Apports de la modélisation géologique 3D et de la chronostratigraphie intégrée. - PhD thesis, Aix-Marseille Univ., 288 p.

Oudet J., Münch Ph., Borgomano J., Quillévéré F., Melinte M., Demo RY F., ViSEUR S. \& CORNÉE J.-J. (2010). - Land and sea study of the northeastern golfe du Lion rifted margin. In: X. LE PICHON and C. Rangin, Eds, Geodynamics of the France Southeast Basin. - Bulletin de la Société géologique de France, 181, 6 , 591-607

Philip J. (1967). - Modalités et importance de la transgression du Sénonien inférieur dans la région de Saint-Cyr-sur-Mer, Var. - Comptes-Rendus de l'Académie des Sciences, Paris, 265, 1883-1886.

PHILIP J. (1970). - Les formations calcaires à rudistes du Crétacé supérieur provençal et rhodanien. - Thèse d'État, Université de Provence, Marseille, $438 \mathrm{p}$.

PHILIP J. (1982). - Rapports entre tectonique et sédimentation carbonatée récifale. Etude d'un modèle provençal. - Géologie Méditerranéenne, 9, 3, 223-227.

Philip J., Masse J.-P. \& Machhour L. (1987). - L'évolution paléogéographique et structurale du front de chevauchement nord-toulonnais (Basse-Provence occidentale, France). - Bulletin de la Société géologique de France, (8), III, 3, 541-550.

Redondo C. (1986). - Etude des sédiments détritiques du Crétacé supérieur marin de la Provence occidentale et recherche des zones d'apport: sédimentologie, pétrographie, minéralogie. - Thèse d'Etat, Université de Provence, 496p.

Rehault J.-P., Boillot G. \& Mauffret A. (1984). - The western Mediterranean basin geological evolution. - Marine Geology, 55 447-477.

Reijmer J.J.G., Palmieri P., Groen R. \& Floquet M. (2015). - Calciturbidites and calcidebrites: Sea-level variations or tectonic proces ses? - Sedimentary Geology, 317, 53-70.

Rollet N. (1999). - Structure profonde et dynamique du Bassin ligure et de ses marges. - PhD thesis, P. et M. Curie Univ., Paris, 324 p.

Rollet N., Deverchere J., Beslier M.-O., Guennoc P., Rehault J.-P. Sosson M. \& TRUfFERT C. (2002). - Back-arc extension, tectonic inheritance and volcanism in the Ligurian Sea, western Mediterranean. - Tectonics, 21, 3, 6-1 - 6-23.
Roure F. \& Choukroune P. (1998). - Contribution of the Ecors seismic data to the Pyrenean geology: Crustal architecture and geodynamic evolution of the Pyrenees. - Mémoires de la Société géologique de France, 173, 37-52.

Rouire J. \& Blanc J.-J. (1979). - Carte géologique de la France à 1/250 000: Feuille Marseille (GC39), carte et notice explicative, 88p. - BRGM, Orléans

Roveri M., Flecker R., Krijgsman W., Lofi J., Lugli S., Manzi V., Sier ro F.J., Bertini A., Camerlenghi A., De Lange G.J., Govers R., Hilgen F.J., Hubscher C., Meijer P.Th. \& Stoica M. (2014). - The Messinian Salinity Crisis: past and future of a great challenge for marine sciences. - Marine Geology, 352, 25-58.

Sage F., Beslier M.-O., Thinon I., Larroque C., Dessa J.-X., Migeon S., Angelier J., Guennoc P., Schreiber D., Michaud F., Stephan J.-F. \& SonnetTe L. (2011). - Structure and evolution of a passive margin in a compressive environment: example of the south western Alps-Ligurian basin junction during the Cenozoic. Marine and Petroleum Geology, 28, 1263-1282.

SÉRANNE M. (1999). - The Gulf of Lion continental margin (NW Mediterranean) revisited by IBS: an overview. In: B. DURAND, L. JOLIVET, F. Horváth and M. SÉrAnne, Eds, The Mediterranean basins: Tertiary extension within the Alpine orogen. - The Geological Society, London, Spec. Publ., 156, 15-36.

Stampfli G.M. \& Borel G.D. (2002). - A plate tectonic model for the Paleozoic and Mesozoic constrained by dynamic plate boundaries and restored synthetic oceanic isochrones. - Earth and Planetary Science Letters, 196, 17-33.

TAssy A. (2012). - Karsts côtiers et canyons sous-marins de la marge provençale au Cénozoïque: Contrôle géodynamique, eustatique, hydrologique et structural. - $\mathrm{PhD}$ thesis, Aix-Marseille Univ. 414 p.

Tassy A., Fournier F., Munch P., Borgomano J., Thinon I., Fabri M.C., Rabineau M., Arfin B., Begot J., Beslier M.-O., Cornee J.-J., Fournillon A., Gorini C., Guennoc P., Leonide P., Oudet J., Paquet F., Sage F. \& Toullec R. (2014). - Discovery of Messinian canyons and new seismic stratigraphic model, offshore Provence (SE France): implications for the hydrographic network reconstruction. - Marine and Petroleum Geology, 57, 25-50.

Tempier J. (1987). - Modèle nouveau de mise en place des structures provençales. - Bulletin de la Société géologique de France, Paris, 8 III, 533-540.

Terrier M., Serrano O. \& Hanot F. (2008). - Reassessment of the structural framework of western Provence (France): consequence on the regional seismotectonic model. - Geodinamica Acta, 21, (5-6), 231-238.

VILLEGER M. (1984). - Evolution tectonique du panneau de couverture Nord-Provençal (Mont-Ventoux, Luberon, Moyenne Durance). $\mathrm{PhD}$ thesis, Univ. Paris-Sud, $175 \mathrm{p}$.

Villeger M. \& ANdrieuX J. (1987). - Phases tectoniques post-Eocènes et structuration polyphasée du panneau de couverture nord provençal (Alpes externes méridionales). - Bulletin de la Société géologique de France, 8, III, 147-156.

ZiEgLeR P.A. (1994). - Cenozoic rift system of western and central Europe: an overview. - Geologie in Mijnbow, 73, 99-127. 